\title{
Satellite evidence of substantial rain-induced soil emissions of ammonia across the Sahel
}

\author{
Jonathan E. Hickman ${ }^{1, a}$, Enrico Dammers ${ }^{2}$, Corinne Galy-Lacaux ${ }^{3}$, and Guido R. van der Werf ${ }^{1}$ \\ ${ }^{1}$ Faculty of Science, Vrije Universiteit, Amsterdam, $1081 \mathrm{HV}$, the Netherlands \\ ${ }^{2}$ Air Quality Research Division, Environment and Climate Change Canada, Toronto, Ontario, M3H 5T4, Canada \\ ${ }^{3}$ Laboratoire d'Aérologie UPS-CNRS UMR 5560, Toulouse, 31400, France \\ anow at: NASA Goddard Institute for Space Studies, New York, 10025, USA
}

Correspondence: Jonathan E. Hickman (jonathan.e.hickman@nasa.gov)

Received: 31 May 2018 - Discussion started: 9 July 2018

Revised: 16 October 2018 - Accepted: 30 October 2018 - Published: 27 November 2018

\begin{abstract}
Atmospheric ammonia $\left(\mathrm{NH}_{3}\right)$ is a precursor to fine particulate matter formation and contributes to nitrogen $(\mathrm{N})$ deposition, with potential implications for the health of humans and ecosystems. Agricultural soils and animal excreta are the primary source of atmospheric $\mathrm{NH}_{3}$, but natural soils can also be an important emitter. In regions with distinct dry and wet seasons such as the Sahel, the start of the rainy season triggers a pulse of biogeochemical activity in surface soils known as the Birch effect, which is often accompanied by emissions of microbially produced gases such as carbon dioxide and nitric oxide. Field and lab studies have sometimes, but not always, observed pulses of $\mathrm{NH}_{3}$ after the wetting of dry soils; however, the potential regional importance of these emissions remains poorly constrained. Here we use satellite retrievals of atmospheric $\mathrm{NH}_{3}$ using the Infrared Atmospheric Sounding Interferometer (IASI) regridded at $0.25^{\circ}$ resolution, in combination with satellite-based observations of precipitation, surface soil moisture, and nitrogen dioxide concentrations, to reveal substantial precipitationinduced pulses of $\mathrm{NH}_{3}$ across the Sahel at the onset of the rainy season in 2008. The highest concentrations of $\mathrm{NH}_{3}$ occur in pulses during March and April when $\mathrm{NH}_{3}$ biomass burning emissions estimated for the region are low. For the region of the Sahel spanning 10 to $16^{\circ} \mathrm{N}$ and 0 to $30^{\circ} \mathrm{E}$, changes in $\mathrm{NH}_{3}$ concentrations are weakly but significantly correlated with changes in soil moisture during the period from mid-March through April when the peak $\mathrm{NH}_{3}$ concentrations occur $(r=0.28, p=0.02)$. The correlation is also present when evaluated on an individual pixel basis during April $(r=0.16, p<0.001)$. Average emissions for the entire
\end{abstract}

Sahel from a simple box model are estimated to be between 2 and $6 \mathrm{mg} \mathrm{NH}_{3} \mathrm{~m}^{-2} \mathrm{~d}^{-1}$ during peaks of the observed pulses, depending on the assumed effective $\mathrm{NH}_{3}$ lifetime. These early season pulses are consistent with surface observations of monthly concentrations, which show an uptick in $\mathrm{NH}_{3}$ concentration at the start of the rainy season for sites in the Sahel. The $\mathrm{NH}_{3}$ concentrations in April are also correlated with increasing tropospheric $\mathrm{NO}_{2}$ concentrations observed by the Ozone Monitoring Instrument $(r=0.78, p<0.0001)$, which have previously been attributed to the Birch effect. Box model results suggest that pulses occurring over a 35day period in March and April are responsible for roughly one-fifth of annual emissions of $\mathrm{NH}_{3}-\mathrm{N}$ from the Sahel. We conclude that precipitation early in the rainy season is responsible for substantial $\mathrm{NH}_{3}$ emissions in the Sahel, likely representing the largest instantaneous fluxes of gas-phase $\mathrm{N}$ from the region during the year.

\section{Introduction}

Ammonia $\left(\mathrm{NH}_{3}\right)$ plays an important role in the atmosphere and in the nitrogen $(\mathrm{N})$ cycle. In the atmosphere, $\mathrm{NH}_{3}$ is a precursor to the formation of fine particulate matter $\left(\mathrm{PM}_{2.5}\right)$, which contributes to substantial levels of premature mortality (Lelieveld et al., 2015). $\mathrm{NH}_{3}$ can also form a substantial proportion of atmospheric $\mathrm{N}$ deposition (Dentener et al., 2006; Holland et al., 2005), affecting downwind ecosystems by potentially altering productivity (Thomas et al., 2009), soil pH (Tian and Niu, 2015), eutrophication status (Bergstrom and 
Jannson, 2006) and biodiversity (Bobbink et al., 2010), as well as stimulating emissions of other trace gases such as nitric oxide (NO) and nitrous oxide $\left(\mathrm{N}_{2} \mathrm{O}\right.$; e.g., Eickenscheidt et al., 2011; Pilegaard et al., 2006).

Cropland and grazed soils have long been known to be a major source of atmospheric ammonia through the volatilization of urea- and ammonium-based $\left(\mathrm{NH}_{4}^{+}\right)$inorganic fertilizers as well as livestock excreta (Bouwman et al., 1997). Ammonia emissions can also represent an important $\mathrm{N}$ flux in natural ecosystems, particularly in drylands. Soil $\mathrm{NH}_{3}$ emissions can represent over $25 \%$ of annual nitrogen losses from desert ecosystems (McCalley and Sparks, 2008) and over $10 \%$ from a semiarid savanna (Soper et al., 2016).

Soil moisture is a key control over biogeochemical cycles in drylands (Austin et al., 2004). Biogeochemical cycling in dryland soils is often characterized by pulsing dynamics related to the wetting or rewetting of dry soils, known as the Birch effect (Birch, 1960; Birch and Friend, 1956). In environments where the distribution of annual precipitation is distinctly seasonal, soil microbial activity typically declines during the dry season as water becomes limiting and microbes senesce or become dormant (Borken and Matzner, 2009). N may build up in soils during this period, when little biological uptake occurs, but when atmospheric $\mathrm{N}$ deposition continues and senesced microbial and plant material accumulates (Borken and Matzner, 2009). The onset of the rainy season can initiate a rapid increase in microbial activity (Birch and Friend, 1956; Borken and Matzner, 2009; Placella and Firestone, 2013; Placella et al., 2012), as reawakened microbes take advantage of pools of $\mathrm{N}$ that accumulated or were made more bioavailable during the dry season, leading to large increases in $\mathrm{N}$ mineralization rates (Birch, 1958; 1960; Borken and Matzner, 2009; Dijkstra et al., 2012; Saetre and Stark, 2004; Semb and Robinson, 1969). The abrupt change in water potential also represents a stress to microbes, prompting a flush of labile $\mathrm{N}$ solutes released by microbes to maintain turgor pressure (Kieft et al., 1987).

This increase in microbial activity is accompanied by pulsed emissions of trace gases such as carbon dioxide $\left(\mathrm{CO}_{2}\right.$; Emmerich, 2003; Huxman et al., 2004; Saetre and Stark, 2004) and NO (e.g., Anderson and Levine, 1986; Davidson, 1992), which can be an important component of annual emissions (Davidson, 1992; Jaeglé et al., 2004). As the availability of $\mathrm{NH}_{4}^{+}$is a major control over $\mathrm{NH}_{3}$ volatilization (Nelson, 1982; Schlesinger and Peterjohn, 1991), a flush of N mineralization and an increase in soil moisture would be expected to trigger an $\mathrm{NH}_{3}$ emission pulse as well. A few studies have documented pulse dynamics in emissions of $\mathrm{NH}_{3}$ in laboratory or field settings (Delon et al., 2017; McCalley and Sparks, 2008; Schlesinger and Peterjohn, 1991; Soper et al., 2016). In arid and semiarid ecosystems, soil $\mathrm{NH}_{3}$ emissions have been observed to increase by $\sim 15 \%$ to $630 \%$ after wetting (Schlesinger and Peterjohn, 1991). However, there are few studies outside desert ecosystems (Kim et al., 2012), and an increase in $\mathrm{NH}_{3}$ emissions following wetting is not al- ways observed (e.g., Yahdjian and Sala, 2010). The potential importance of these pulse emissions of $\mathrm{NH}_{3}$ at landscape or regional scales remains poorly constrained.

In addition to $\mathrm{NH}_{4}^{+}$availability, soil $\mathrm{pH}$ is a key environmental control over $\mathrm{NH}_{3}$ production in soils (Dawson, 1977; Nelson, 1982). Since $\mathrm{NH}_{3}$ is typically produced through the deprotonation of $\mathrm{NH}_{4}^{+}, \mathrm{NH}_{3}$ emissions would be expected to be higher in relatively alkaline soils or in soil with alkaline microsites. Globally, soils tend to shift from alkaline to acidic when mean annual precipitation exceeds mean annual evapotranspiration (Slessarev et al., 2016), so soils in drier biomes such as deserts and grasslands tend to be alkaline (though there are exceptions to this pattern), creating conditions favorable to $\mathrm{NH}_{3}$ volatilization. For example, the combination of $\mathrm{pH}$ and ammonium concentrations in soils from a semiarid ecosystem in Senegal have been shown to create conditions favorable to the emission of $\mathrm{NH}_{3}$ (Delon et al., 2017).

Given the importance of rainfall seasonality, soil $\mathrm{pH}$, and $\mathrm{N}$ availability in contributing to $\mathrm{NH}_{3}$ emission pulses, soils in the Sahel may be an important source of $\mathrm{NH}_{3}$ to the atmosphere during the onset of the rainy season and a case study for determining whether Birch effect $\mathrm{NH}_{3}$ pulsing is an important process at broad regional scales. The Sahel is a grassland environment representing a transition between desert and productive savannas. It is characterized by a unimodal rainfall seasonality, with mean annual precipitation typically ranging between 100 and $600 \mathrm{~mm} \mathrm{yr}^{-1}$. Seasonal variation in rainfall is broadly determined by the movement of the Intertropical Convergence Zone (ITCZ). Migration of the ITCZ north of the Equator in the first half of the calendar year is accompanied by the onset of the rainy season and West African monsoon, with the first substantial rain events occurring in April. The southward retreat of the ITCZ marks the start of the dry season in the Sahel in October or November. Recent maps of African soils based on surface reflectance suggest that soils across the Sahel tend to have pHs largely near neutral, but can be higher than 9 in some areas (Vågen et al., 2016). The combination of seasonal rainfall variability and soils with neutral or alkaline pHs suggests that Sahelian soils may be an important source of $\mathrm{NH}_{3}$ at the onset of the rainy season. The Sahel is characterized by lower levels of fertilizer inputs (FAO, accessed 2018) and smaller loads of atmospheric $\mathrm{N}$ deposition than other parts of the world (Dentener et al., 2006; Galy-Lacaux and Delon, 2014; Laouali et al., 2012; though deposition can be elevated at the Sahel's southern boundary). However, it has moderately high livestock densities (Robinson et al., 2014), potentially providing sites of abundant available $\mathrm{N}$ for the production of $\mathrm{NH}_{3}$. Indeed, soil $\mathrm{NH}_{3}$ emissions have been shown to be higher at a site in northern Senegal following a rain event (Delon et al., 2017).

Earlier work using total column observations from the GOME instrument presented evidence of high atmospheric concentrations of nitrogen dioxide $\left(\mathrm{NO}_{2}\right)$ over the Sahel in the early rainy season of 2000 , which appeared to broadly 
correspond to rainfall events in the region (Jaeglé et al., 2004). These early growing season increases in tropospheric $\mathrm{NO}_{2}$ concentrations could not be attributed to lightning or to biomass burning, leaving soil emissions the presumed source. Soils emit NO through a variety of biotic and abiotic mechanisms; in the atmosphere, NO rapidly interconverts to $\mathrm{NO}_{2}$, and the two gases are collectively referred to as $\mathrm{NO}_{x}$. Inverse modeling subsequently suggested that soil emissions of NO across sub-Saharan Africa were of the same magnitude as emissions from biomass burning, which previously had been thought to be the dominant $\mathrm{NO}_{x}$ source in the region (Jaeglé et al., 2004). Note that in this paper, NO is used in discussions of soil emissions specifically. Since satellite observations are limited to $\mathrm{NO}_{2}$, we use $\mathrm{NO}_{2}$ when discussing those observations and $\mathrm{NO}_{2}$ or $\mathrm{NO}_{x}$ when discussing modeled surface emissions based on those observations.

At regional scales, the processes controlling seasonal variability in emissions, and the magnitude of emission responses to these controls, are not well constrained. Atmospheric models often rely on static emissions inventories of $\mathrm{NH}_{3}$ that lack intra-annual variability or detailed environmental controls over emissions from soils (e.g., Bouwman et al., 1997; European Commission, Joint Research Center (JRC)/Netherlands Environmental Agency (PBL), 2011; Lamarque et al., 2010), particularly for natural ecosystems (e.g., Paulot and Jacob, 2014). Fire emission inventories are generally created using data on burned area, fuel load, combustion completeness to compute dry matter of carbon losses, and emission factors that translate these data into trace gas or aerosol emissions, producing daily emissions estimates at $0.25^{\circ}$ resolution (e.g., van der Werf et al., 2017). Inventories of $\mathrm{NH}_{3}$ emissions from natural soils tend to rely on a global estimate for the year 1990 (Bouwman et al., 1997), and agricultural emission inventories with sub-annual temporal resolution tend not to consider environmental controls other than temperature and wind speed (e.g., Paulot and Jacob, 2014).

Here we use satellite retrievals of atmospheric $\mathrm{NH}_{3}$ concentrations (Whitburn et al., 2016) over Africa to evaluate whether the onset of the rainy season causes pulsed emissions of $\mathrm{NH}_{3}$ over the Sahel, focusing on the year 2008, and evaluate its environmental drivers. We compare the seasonal pattern in atmospheric $\mathrm{NH}_{3}$ concentrations observed by satellite to monthly surface $\mathrm{NH}_{3}$ deposition measured at seven sites in north equatorial Africa. We also use a simple box model to calculate surface fluxes based on retrieved atmospheric concentrations and compare modeled surface fluxes to $\mathrm{NH}_{3}$ emissions from biomass burning as quantified in the Global Fire Emissions Database 4s (GFED4s; van der Werf et al., 2017). Finally, we make comparisons to modeled surface fluxes of $\mathrm{NO}_{2}$ derived from $\mathrm{NO}_{2}$ observations made by the Ozone Monitoring Instrument (OMI; Krotkov, 2018).

\section{Methods}

\subsection{Satellite products}

The Infrared Atmospheric Sounding Interferometer (IASIA), launched aboard the European Space Agency's MetOp$A$ in 2006, obtains retrievals of atmospheric $\mathrm{NH}_{3}$ at a global distribution and bi-daily resolution. IASI-A is a polarorbiting instrument in a sun-synchronous orbit (09:30 local solar time Equator crossing, descending node), providing two observations daily; here we use morning observations when the thermal contrast is more favorable for retrievals (Clarisse et al., 2009; Van Damme et al., 2014). IASI-A provides a horizontal resolution of $12 \mathrm{~km}$ over a swath width of about $2200 \mathrm{~km}$. The retrieval product used follows the approach implemented by Whitburn et al. (2016), in which total columns of $\mathrm{NH}_{3}$ are obtained by calculating a dimensionless spectral index (HRI), which is then converted into an $\mathrm{NH}_{3}$ total column through the use of a neural network. The neural network uses a range of variables such as temperature and water vapor profiles to represent the state of the atmosphere as best as possible to produce the matching $\mathrm{NH}_{3}$ total column for that atmospheric state. Retrievals with errors above $100 \%$ were excluded from the analysis, though exceptions were made for low concentrations, which tend to have a higher error, when the following condition was met:

$$
\begin{aligned}
& \text { Retrieval error } \times \text { total column } \mathrm{NH}_{3} \times 0.01 \\
& \quad<5 \times 10^{15} \text { molecules } \mathrm{cm}^{-2}
\end{aligned}
$$

where the retrieval error is a percentage and the total column $\mathrm{NH}_{3}$ is a concentration in molecules $\mathrm{cm}^{-2}$. In addition, only retrievals that were at least $75 \%$ cloud-free were used. Given the absence of hourly observations in the Sahel, the detection limit of IASI is difficult to determine with certainty. However, the region experiences high thermal contrast, and IASI seems to be able to reliably observe down to 1 to $2 \mathrm{ppb}$ at the surface (Van Damme et al., 2014). We regridded the level2 IASI $\mathrm{NH}_{3}$ product to $0.25^{\circ} \times 0.25^{\circ}$ resolution to match the resolution of soil moisture and other data used in the analysis. Specifically, we calculated the concentration for a given grid cell as the mean of all elliptical IASI footprints for which the corners of the grid cell were within the footprint. The IASI product has been validated using ground-based Fourier transform infrared (FTIR) observations of $\mathrm{NH}_{3}$ total columns, with robust correlations at sites with high $\mathrm{NH}_{3}$ concentrations, but lower at sites where atmospheric concentrations approach IASI's detection limits (Dammers et al., 2017). Compared to the FTIR observations the IASI total columns are biased low by $\sim 30 \%$, which varies per region depending on the local concentrations. 
We used the Tropical Rainfall Measuring Mission (TRMM) daily precipitation product (3B42), which is based on a combination of TRMM observations, geosynchronous infrared observations, and rain gauge observations (Huffman et al., 2007). Independent rain gauge observations from West Africa have been used to validate the product, with no indication of bias in the product (Nicholson et al., 2003).

We used the European Space Agency's Climate Change Initiative (ESA-CCI) 30-year daily soil moisture product gridded at $0.25^{\circ} \times 0.25^{\circ}$ resolution (Dorigo et al., 2017; Gruber et al., 2017; Liu et al., 2012). The product is based on both passive and active microwave sensors and has been validated globally (Dorigo et al., 2014) and in East Africa (McNally et al., 2016). Although the product exhibited moderate correlation with ground observations globally, it provides relatively high correlations $\left(r \sim 0.7\right.$ molecules $\left.\mathrm{cm}^{-2}\right)$ for sites when seasonality is included in the analysis (Dorigo et al., 2014).

We also used the publicly available level-3 tropospheric $\mathrm{NO}_{2}$ concentrations product from OMI, a nadir-viewing spectrometer measuring solar backscatter in the UV-visible range aboard NASA's Aura satellite (Krotkov et al., 2017, Krotkov, 2018). The product is cloud-screened, including only pixels that are at least $70 \%$ cloud-free and provided at $0.25^{\circ} \times 0.25^{\circ}$ resolution. The OMI product relies on air mass factors calculated with the assistance of an atmospheric chemical transport model and is sensitive to model representations of emission, chemistry, and transport data. These are generally poorly constrained for regions not commonly analyzed in chemical transport models such as sub-Saharan Africa (McLinden et al., 2014). Additional bias may be introduced due to the reliance on nearly cloud-free pixels, in which greater sunlight may induce higher photochemical rates. For example, the current product is biased roughly $30 \%$ low over the Canadian oil sands (McLinden et al., 2014). The level-2 OMI-NO 2 product has been validated against in situ and surface-based observations showing good agreement (Lamsal et al., 2014). In statistical analyses, soil moisture, precipitation, and $\mathrm{NO}_{2}$ data were masked to match pixels for which $\mathrm{NH}_{3}$ retrievals were also available.

\subsection{Surface flux calculations}

A range of possible surface fluxes of $\mathrm{NH}_{3}$ and $\mathrm{NO}_{2}$ from our focal study region in the Sahel, ranging from 10 to $16^{\circ} \mathrm{N}$ and from 0 to $30^{\circ} \mathrm{E}$, were calculated from IASI total column $\mathrm{NH}_{3}$ concentrations and OMI-NO 2 tropospheric concentrations using a simple box model (Jacob, 1999). The specific region was selected as representative of the Sahel and to allow for direct comparisons to earlier work examining $\mathrm{NO}_{2}$ emissions from the region (Jaeglé et al., 2004). Daily mean gridded concentrations of retrievals for each gas were averaged across the focal region with units of molecules $\mathrm{cm}^{-2}$. The mean total column concentrations of gas $x$ were converted to a mean surface density for the region in units of $\mathrm{kg} \mathrm{m}^{-2}$ for each day using the following equation:

$M_{x, t}=\left(\mathrm{TC}_{x, t} \times \mathrm{MM}_{x} \times 10\right) / N_{\mathrm{a}}$,

where $M_{x, t}$ is the mean surface density of gas $x$ for day $t$, $\mathrm{TC}_{x, t}$ is the average of retrieved total columns of gas $x$ in units of molecules $\mathrm{cm}^{-2}$ for day $t, \mathrm{MM}_{x}$ is the molar mass of gas $x$, and $N_{\mathrm{a}}$ is Avogadro's number. The dividend on the right-hand side of Eq. (2) is multiplied by 10 to convert the mean surface density to units of $\mathrm{kg} \mathrm{m}^{-2}$. This mean surface density was then used in the box model to calculate a mean surface flux for each day, assuming first-order losses of gas $x$ :

$E_{x, t}(\mathrm{~mol})=\frac{\left(M_{x, t}-M_{x, t-d} e^{-d / \tau_{x}}\right)}{\tau_{x}\left(1-e^{-d / \tau_{x}}\right)}$,

where $E_{x, t}$ is the surface flux on day $t$ in units of $\mathrm{kg} \mathrm{m}^{-2} \mathrm{~d}^{-1}$, $d$ is the time between subsequent observations ( 1 day in this study), and $\tau_{x}$ is the effective lifetime of a molecule of gas $x$, including both reactive and transport losses. As both the effective lifetime and the surface flux are unknowns in Eq. (3), we use a range of plausible lifetimes for each gas to calculate a range of surface fluxes. For $\mathrm{NH}_{3}$, we use lifetimes of 6, 12, 24, and 36 h (Dentener and Crutzen, 1994; Whitburn et al., 2015); for $\mathrm{NO}_{2}$, we use lifetimes of 6,12 , and $24 \mathrm{~h}$ (Beirle et al., 2011; de Foy et al., 2015; Jena et al., 2014). The values were selected to reflect the possible range of lifetimes throughout the year, including periods of elevated wet deposition during the rainy season. Our box-modeled $\mathrm{NO}_{2}$ emissions used only satellite observations for grid cells in which $\mathrm{NH}_{3}$ observations were also present, whereas the boxmodeled $\mathrm{NH}_{3}$ emissions used all available $\mathrm{NH}_{3}$ observations. Modeled $\mathrm{NH}_{3}$ results restricted to using satellite observations for grid cells in which $\mathrm{NO}_{2}$ observations were also present are included in the Supplement to allow for more direct comparisons between modeled $\mathrm{NO}_{2}$ and modeled $\mathrm{NH}_{3}$ emissions.

\subsection{Emissions inventory}

GFED4s (van der Werf et al., 2017) provides monthly fire emissions at $0.25^{\circ}$ resolution based on satellite-derived burned area (Giglio et al., 2013; Randerson et al., 2012) and a modified version of the Carnegie-Ames-Stanford Approach (CASA) biogeochemical model (Potter et al., 1993). Daily emissions are calculated using data on the fraction of monthly emissions emitted on each date. Uncertainty in GFED fire emissions stems from uncertainty in burned area, fuel consumption, and emission factors but is poorly constrained. According to van der Werf et al. (2017) a $1 \sigma$ of about $50 \%$ for fire carbon emissions is reasonable for continental-scale estimates. This may also be a best-guess estimate for fire $\mathrm{NH}_{3}$ emissions in our study region; while the uncertainty in $\mathrm{NH}_{3}$ emission factors is large because few fires have been sampled, which adds to the total uncertainty, 
burned area and fuel consumption in savannas are, in general, better constrained than in other biomes.

\subsection{Statistical analyses}

Pearson product moment correlation analyses were conducted using pearsonr from the scipy.stats package in Python v3.6.3.

\section{Results and discussion}

The wetting of dry soils has been known to stimulate biogeochemical cycling since at least the 1950s. Its role in creating large pulsed emissions of trace gases such as $\mathrm{CO}_{2}$ and NO has been demonstrated at laboratory (e.g., Birch and Friend, 1956), field (e.g., Davidson, 1992), and regional scales through satellite observations (Jaeglé et al., 2004) and observation networks (Adon et al., 2010). Evidence for its importance to emissions of $\mathrm{NH}_{3}$ has been limited to a few laboratory and field studies, with sometimes contrasting results, and its importance at landscape or regional scales is not well constrained. Here we present evidence that the Birch effect is an important driver of $\mathrm{NH}_{3}$ emissions at regional scales and is likely responsible for the periods of the highest atmospheric $\mathrm{NH}_{3}$ concentrations over the Sahel region in Africa.

\subsection{Seasonal variability in $\mathrm{NH}_{3}$ concentrations over Africa}

Atmospheric $\mathrm{NH}_{3}$ concentrations in 2008 exhibited broad seasonality that appears to correspond to seasonal precipitation patterns across the continent (Fig. 1). In January, mean monthly concentrations are highest across a latitudinal band from roughly 5 to $10^{\circ} \mathrm{N}$, broadly corresponding to the region of highest biomass burning emissions (Fig. 1). In April, higher cumulative monthly precipitation across the southern Sahel coincides with increased mean monthly $\mathrm{NH}_{3}$ concentrations in the focal region (the red box in Fig. 1b); fire emissions are generally absent across the Sahel and much of the rest of the continent in April, with some emissions occurring along coastal West Africa. By August, during the middle of the West African monsoon, hot spots of ammonia concentrations are generally absent from the continent, though concentrations are slightly elevated in central southern Africa, where emissions from biomass burning are also elevated (Fig. 1).

\subsection{Evidence for precipitation-induced emissions of $\mathrm{NH}_{3}$ in the Sahel}

For our focal region of the Sahel (defined above and outlined in red in Fig. 1), mean atmospheric $\mathrm{NH}_{3}$ concentrations exhibit two distinct peaks in late March and April (Fig. 2a, highlighted in light and dark pink, respectively), which rep- resent the highest concentrations observed in 2008. The late March peak occurs at the same time as an apparent modest increase in mean soil moisture (Fig. 2b). The peak in April, during which atmospheric $\mathrm{NH}_{3}$ concentrations over the Sahel are elevated relative to other parts of north equatorial Africa (Fig. 3a), occurs during the first period of sustained rainfall in the focal region and corresponds to a peak in soil moisture, suggesting a possible causal relationship between changes in soil moisture and atmospheric $\mathrm{NH}_{3}$ concentrations (Fig. 2b and Sect. 3.2.1 below). This increase does occur following a possible modest increase in mean fire emissions (Fig. 2a) across the Sahel. Overall, however, the seasonality in IASIretrieved atmospheric $\mathrm{NH}_{3}$ concentrations exhibits a marked difference from the seasonality in GFED4s $\mathrm{NH}_{3}$ emissions from fires, which start increasing in September and peak in November (Fig. 2a and Sect. 3.2.2 below).

\subsubsection{Soil moisture controls over early growing season atmospheric $\mathrm{NH}_{3}$ concentrations}

Multiple lines of evidence support a causal relationship between changes in soil moisture and atmospheric $\mathrm{NH}_{3}$ concentrations across the Sahel. Foremost are the significant correlations between ESA-CCI's soil moisture product and the IASI total column during the onset of the rainy season. Specifically, for the period from 23 February to 1 May 2008, there is a significant correlation between mean atmospheric $\mathrm{NH}_{3}$ concentrations of all pixels with acceptable retrievals in the Sahel focal region and mean soil moisture across the same set of pixels $(r=0.28, p=0.02$; Fig. $4 \mathrm{a})$. This correlation integrates all pixels across the Sahel and thus excludes any subregional spatial structure in the data. To examine whether a relationship between soil moisture and $\mathrm{NH}_{3}$ concentrations is also present at a finer spatial scale, we conducted a correlation between the two variables for each pixel for which both variables were present during April and again found a significant positive linear correlation $(r=0.16, p<$ 0.001; Fig. 4b). Maps of 3-day averages for precipitation, soil moisture, and total column $\mathrm{NH}_{3}$ concentration over the southern Sahel at $0.25^{\circ}$ resolution illustrate the changes in each variable that occur during the development of the April emissions peak (Fig. 5). Between 13 and 27 April, precipitation events in the southern half of the focal region (Fig. 5a) appear to be accompanied by steady increases in soil moisture (Fig. 5b) and total column $\mathrm{NH}_{3}$ (Fig. 5c).

Although the explanatory power of the correlations between ESA-CCI's soil moisture product and the IASI total column $\mathrm{NH}_{3}$ concentrations is relatively low, it demonstrates a broad regional correlation between $\mathrm{NH}_{3}$ concentrations and changes in soil moisture at the onset of the rainy season - a relationship that is strong enough to be observed at the scale of the Sahel. To provide some context for the statistical result, earlier work finding that rainfall is responsible for large emissions of $\mathrm{NO}_{2}$ in the same region did not include any statistical analysis in support of the findings (Jaeglé et al., 

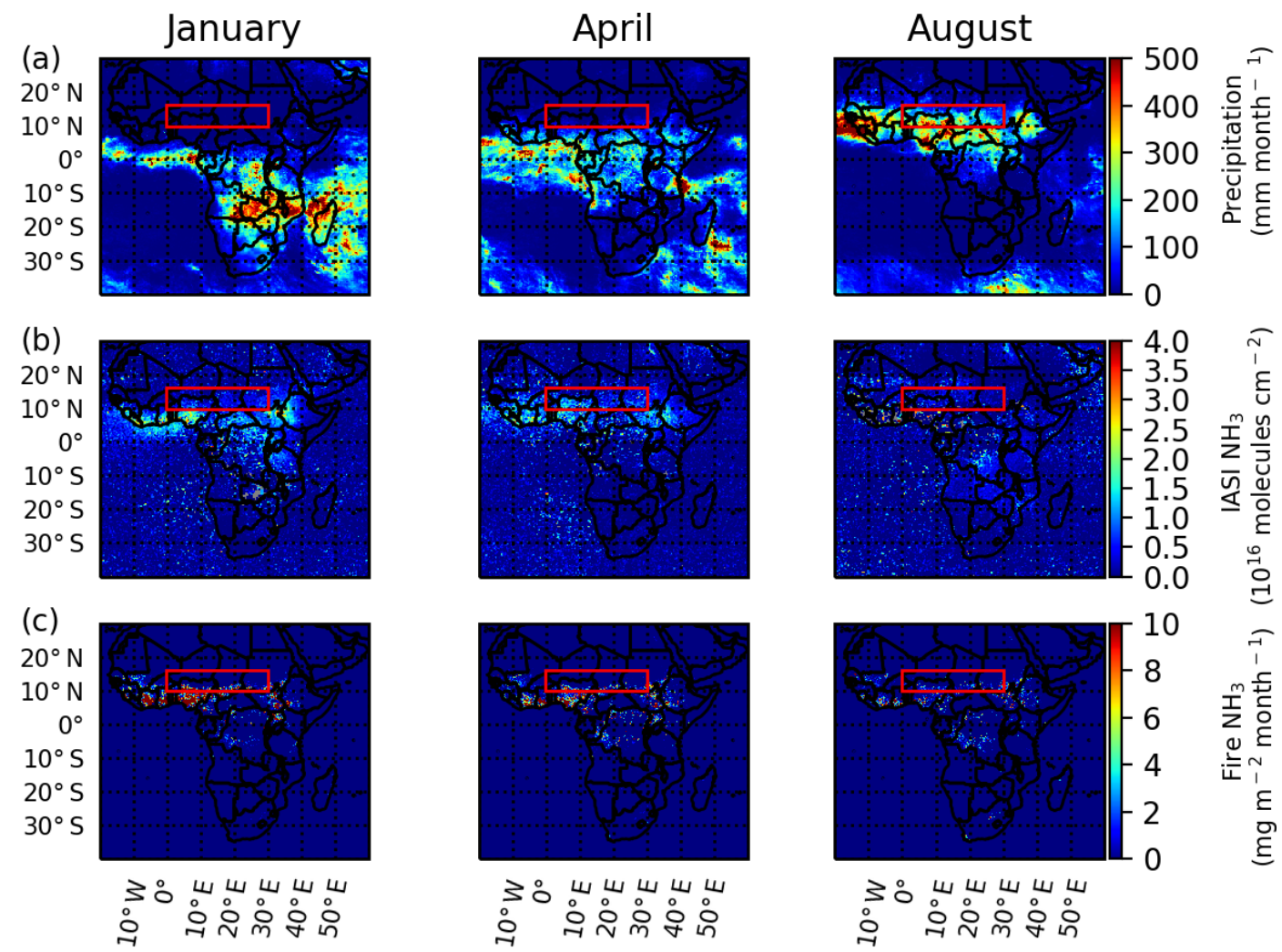

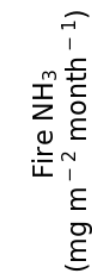

Figure 1. Seasonality of precipitation and $\mathrm{NH}_{3}$ emissions in Africa during 2008. Monthly TRMM precipitation (a), IASI-NH 3 concentrations (b), and GFED4s $\mathrm{NH}_{3}$ emissions (c) over Africa in January, April, and August 2008.

2004), and studies using satellite observations to infer environmental controls interpret correlation coefficients of the order of 0.25 to be evidence of a strong effect (e.g., Andela et al., 2017). Additionally, we would not necessarily expect a linear relationship between the quantity of soil moisture and the quantity of $\mathrm{NH}_{3}$ emitted - the emission response is a function of complex processes that vary over time. Multiple studies have shown that rewetting of dry soils results in lower emission pulses for the same level of water addition (Davidson, 1992; Davidson et al., 1991), including of $\mathrm{NH}_{3}$ emissions (Soper et al., 2016). It also seems plausible that there are threshold effects in which an initial increase in soil moisture may simply need to be large enough to activate dormant microbial communities and/or cause a flush of labile microbial $\mathrm{N}$ to trigger an emissions pulse such that the pulse response might best be described with a piecewise function. Asynchrony between plant and microbial activity during soil wet-up and dry-down (Collins et al., 2008), and different activation thresholds for microbial and plant responses to precipitation (Dijkstra et al., 2012), may also play a role in determining the amount of available $\mathrm{NH}_{4}^{+}$for volatilization at different times in the early rainy season.

\subsubsection{Minimal contribution of fire emissions to early growing season pulses}

We can further exclude biomass burning as the source of the observed pulses of atmospheric $\mathrm{NH}_{3}$. Biomass burning occurs in the Sahel with a well-known seasonality as based on several independent satellite fire metrics such as burned area and active fire detections (Duncan, 2003; Giglio et al., 2006). In general, burning in the Sahel occurs in the second half of the year, and few emissions are expected at the onset of the rainy season (Figs. 1,2). A comparison between our simple box model estimates of $\mathrm{NH}_{3}$ flux and emissions from the GFED4s inventory strongly supports the hypothesis that biomass burning does not play an important role in $\mathrm{NH}_{3}$ emissions during March or April and further suggests that biomass burning may represent a relatively unimportant regional source of $\mathrm{NH}_{3}$ during most of the year, outside of the biomass burning season (Fig. 6). The modeled total surface flux based on IASI observations varies depending on the effective lifetime used by up to a factor of roughly 4 , with seasonal patterns mirroring the patterns in atmospheric concentration and the largest emissions occurring during the pulses in March and April (Fig. 6). In contrast, fire emissions of $\mathrm{NH}_{3}$ from GFED4s are concentrated in the second half of the year and are negligible during March and April, suggest- 

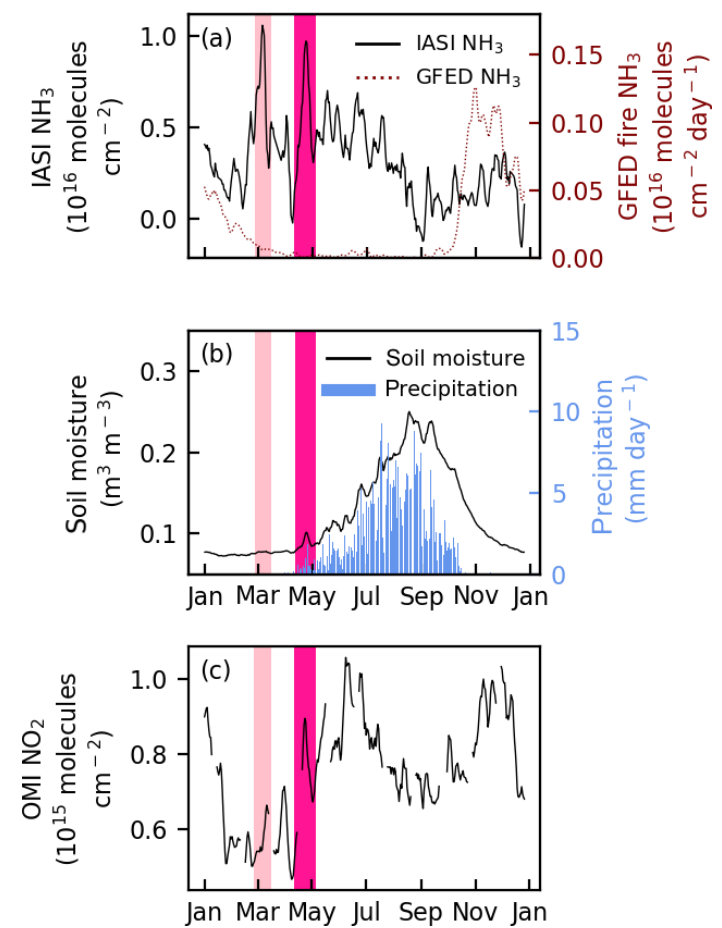

Figure 2. Early growing season $\mathrm{NH}_{3}$ pulses temporally associated with changes in soil moisture and with $\mathrm{NO}_{2}$ pulses over the focal study region in the Sahel during 2008. (a) Daily atmospheric $\mathrm{NH}_{3}$ concentrations from IASI and $\mathrm{NH}_{3}$ biomass burning emissions from GFED4s. (b) ESA-CCI soil moisture and TRMM precipitation. (c) Tropospheric $\mathrm{NO}_{2}$ concentrations from OMI. Putative soil emission pulses in March and April are highlighted in bright and dark pink, respectively. Mean $\mathrm{NO}_{2}$ concentrations were calculated using values of $0.25^{\circ}$ grid cells within the study region for which $\mathrm{NH}_{3}$ observations were also present. GFED4s emissions were converted from a mass-based to molecule-based flux to allow for comparison with the IASI retrievals; note the different scales for the left and right $y$ axes of panel (a).

ing that they do not contribute to the early growing season emission pulses.

The importance of a source of $\mathrm{NH}_{3}$ other than biomass burning in equatorial North Africa was suggested earlier for 0 to $10^{\circ} \mathrm{N}$, a region immediately south of the Sahel and of the southern boundary of our focal region in Figs. 1 and 2 (Van Damme et al., 2015; Whitburn et al., 2015). Whitburn et al. (2015) observe a 1- to 2-month lag between peak fire radiative power and IASI-NH $\mathrm{NH}_{3}$ that differs from the pattern of IASI carbon monoxide (CO) concentrations, suggesting that fire emissions can explain only some of the atmospheric $\mathrm{NH}_{3}$ present. They speculate that soils may be the source of $\mathrm{NH}_{3}$ emissions following the fire season, perhaps resulting from an increase in volatilization caused by increasing soil temperatures and $\mathrm{pH}$, though the paper is focused on evaluating fire emissions and they do not test this hypothesis (Whitburn et al., 2015). Van Damme et al., 2015 speculate that the emissions are agricultural in nature (Van Damme et al., 2015). IASI-NH $\mathrm{NH}_{3}$ concentrations in the other regions examined (southern Africa, Southeast Asia, and central South America) generally track fire activity or are thought to be due to anthropogenic emissions (Whitburn et al., 2015). Although we have focused on the Sahel, it seems possible that the seasonality of rainfall in environments further south, between 0 and $10^{\circ} \mathrm{N}$, might contribute to the elevated concentrations observed there following the end of the fire season.

\subsubsection{Co-emission of $\mathrm{NH}_{3}$ and $\mathrm{NO}_{x}$}

The peak in $\mathrm{NH}_{3}$ concentrations in April occurs at the same time as a peak in $\mathrm{NO}_{2}$ concentrations (though unlike $\mathrm{NH}_{3}$, the April peak does not represent the highest annual atmospheric concentration of $\mathrm{NO}_{2}$ ). For the month of April, total column $\mathrm{NH}_{3}$ concentrations and tropospheric $\mathrm{NO}_{2}$ concentrations integrated across the entire focal region are strongly correlated $(r=0.78, p<0.0001)$. This simultaneous increase in atmospheric $\mathrm{NO}_{2}$ and $\mathrm{NH}_{3}$ concentrations provides additional indirect support for a soil source of $\mathrm{NH}_{3}$ (Figs. 2, 6). In addition to abundant field and laboratory evidence that previously dry soils emit large pulses of NO following wetting (Davidson, 1992; Davidson et al., 1991; Dick et al., 2001; Meixner et al., 1997), Jaeglé et al. (2004) showed that this soil NO pulse is responsible for the highest concentrations of atmospheric $\mathrm{NO}_{2}$ over the same region we focused on. As with the seasonal pattern in $\mathrm{NH}_{3}$ concentrations, seasonal variation in $\mathrm{OMI}-\mathrm{NO}_{2}$ tropospheric concentrations does not match that of the GFED4s $\mathrm{NO}_{2}$ emissions from fires (Fig. 6). We believe that the simplest explanation for our box model results showing the strong correlation between tropospheric $\mathrm{NO}_{2}$ and total column $\mathrm{NH}_{3}$ concentrations in April is that the two pulses are the result of soil emissions triggered by the same environmental change - in this case, an increase in soil moisture following an extended dry period.

Like $\mathrm{NH}_{3}$, concentrations of $\mathrm{NO}_{2}$ also exhibit a peak in mid-March, but the peak lags a week behind the $\mathrm{NH}_{3}$ peak (Fig. 2). Although NO emissions from soils can peak within hours after wetting (Davidson, 1992), in a laboratory setting using soils from the Mojave Desert, an NO pulse lagged 1 to 2 days behind an $\mathrm{NH}_{3}$ pulse following experimental wetting (McCalley and Sparks, 2008). The authors argue that this lag may be related to competition for $\mathrm{NH}_{4}^{+}$between $\mathrm{NH}_{3}$ volatilization and nitrification, with volatilization generally outcompeting nitrification during the initial period following wetting. An alternative or additional contributing factor to the lag may be related to the population dynamics of nitrifying bacteria. Although the transcriptional response of nitrifiers to wetting can be very rapid (Placella and Firestone, 2013), at a population level nitrifiers are generally slow-growing (Robertson and Groffman, 2007), suggesting that populations in resource-limited environments may not be able to immediately take advantage of sudden large increases in resource availability. For example, NO emission 


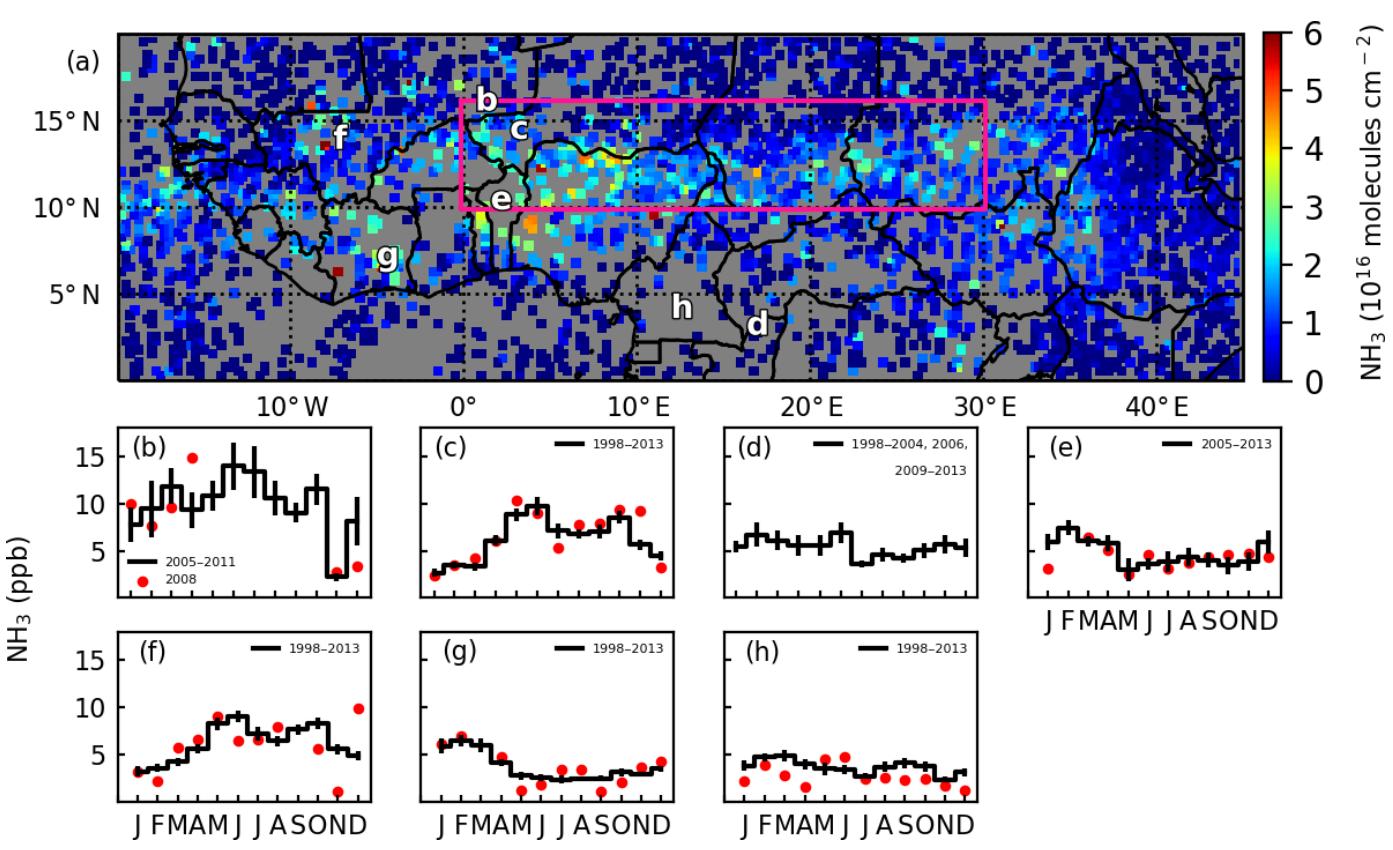

Figure 3. $\mathrm{NH}_{3}$ pulsing over the Sahel in April and geographic variation in the seasonality of surface $\mathrm{NH}_{3}$ concentrations over north equatorial Africa. (a) Observations by IASI during 25 to 28 April 2008 reveal elevated mean atmospheric $\mathrm{NH}_{3}$ concentrations specifically over the Sahel region.(b-h) Monthly $\mathrm{NH}_{3}$ gas concentrations from sites in the INDAAF network; black lines represent the multiyear mean and standard error for each site, and red dots represent the 2008 value. Data are presented for Agoufou, Mali (b), Banizoumbou, Niger (c), Bomassa, Congo (d), Djougou, Benin (e), Katibougou, Mali (f), Lamto, Côte d'Ivoire (g), and Zoétélé, Cameroon (h).

responses to inorganic $\mathrm{N}$ inputs - which arguably provides a similar immediate release from a resource limitation as wetting of dry soils for nitrifiers, particularly in relation to the presumed increase in $\mathrm{NH}_{4}^{+}$concentrations caused by wetting - exhibited pulse responses that lagged roughly a week behind fertilizer additions in Kenya (Hickman et al., 2017). In the case of the Sahel, nitrifier populations may not be able to recover quickly from the extended dry conditions in March, and a lagged emission response of $\mathrm{NO}$ could be explained by the slow population-level response to the flush of mineralized $\mathrm{N}$ that follows wetting.

The March $\mathrm{NO}_{2}$ peak is also smaller than the April $\mathrm{NO}_{2}$ peak and smaller than the April $\mathrm{NH}_{3}$ peak. Field studies have observed larger pulses following the second rainfall of the season (Meixner et al., 1997). The initial increase in soil moisture during March was modest (Fig. 2), so it seems possible that soils dried out quickly before populations of nitrifying bacteria grew large enough to trigger an NO pulse of the magnitude that occurs in April. Increased competition for available $\mathrm{NH}_{4}^{+}$by nitrifying bacteria in April may have limited the $\mathrm{NH}_{3}$ pulse.

There is also a clear mismatch in the timing of the peak $\mathrm{NH}_{3}$ concentrations, which occurred in March and April, and peak $\mathrm{NO}_{2}$ concentrations, which occurred in May and June (Fig. 2). We believe that several factors are likely contributing to the different temporal dynamics of $\mathrm{NH}_{3}$ and $\mathrm{NO}_{2}$ concentrations. First, to be clear, we argue that the rainfall events in March and April are indeed triggering pulses of both gases, illustrated in part by the strong correlation between the two gases during April $(r=0.78, p<0.0001$; Fig. 2 ; for a strict comparison in which concentrations of $\mathrm{NO}_{2}$ and $\mathrm{NH}_{3}$ are calculated using only grid cells that have observations for both gases, see Fig. S1 in the Supplement, though the results are qualitatively similar to Fig. 2). Temporal patterns of surface $\mathrm{NO}_{2}$ concentrations observed by the International Network to study Deposition and Atmospheric chemistry in Africa (INDAAF; last accessed December 2017) may also support the presence of these smaller early pulses (Fig. S2). Although not explicitly investigated, we believe earlier studies of $\mathrm{NO}_{2}$ pulsing in the Sahel that focus on emissions during May and June include observations of similar early season pulses (Jaeglé et al., 2004; Hudman et al., 2012).

The early season $\mathrm{NO}_{2}$ pulses may be small as a result of the nitrifier population dynamics alluded to above. Specifically, because population growth is slow, nitrifying populations are smaller during March and April than they will become later in the growing season when they are released from sustained environmental limitations on growth, so nitrification rates remain lower in these early responses. In an earlier field study conducted in Davis, California, which also experiences distinct dry and rainy seasons, nitrifier population growth rates were very slow to respond to ammonium additions, roughly matching the temporal patterns of $\mathrm{NO}_{2}$ emissions we observed in the Sahel (Okano et al., 2004). In 


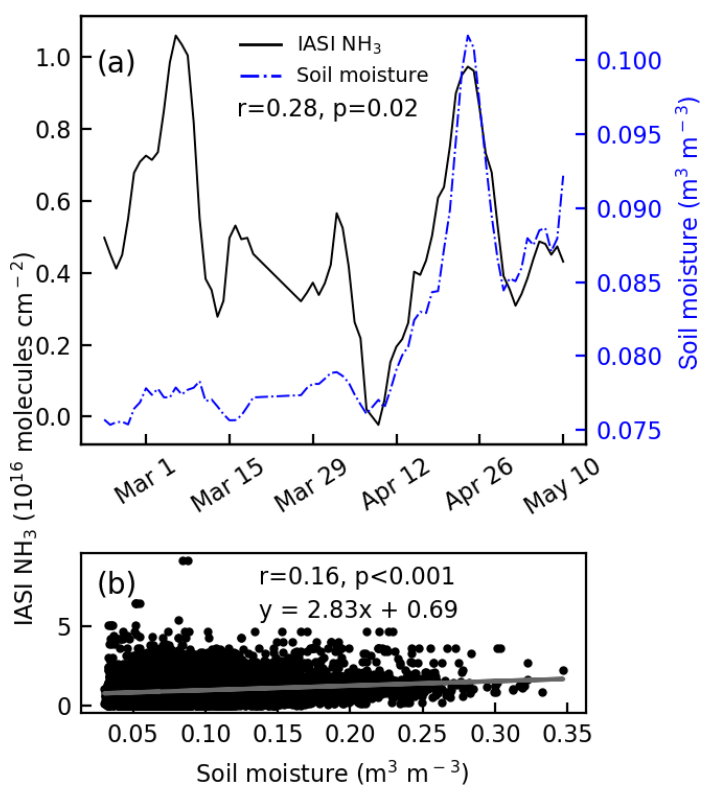

Figure 4. Correlations between soil moisture and atmospheric $\mathrm{NH}_{3}$ concentrations observed by IASI over the focal study region in the Sahel during the start of the rainy season in 2008. (a) 5-day running mean of daily $\mathrm{NH}_{3}$ concentrations and daily soil moisture for the focal study region from mid-February through the end of April 2008. (b) Scatterplot of soil moisture versus atmospheric $\mathrm{NH}_{3}$ concentration for each $0.25^{\circ}$ grid cell in the study region during April 2008 . In both panels, soil moisture data are included only for those $0.25^{\circ}$ grid cells in which $\mathrm{NH}_{3}$ observations are available for the same day.

that study, population size did not increase during the first week following ammonium sulfate applications, and then rose by roughly $50 \%$ in the second week. Between the 13th and 39th day, however, the population roughly tripled. In the Sahel, nitrifying populations are presumably released from widespread water limitation around the beginning of May (Fig. 2), and $\mathrm{NO}_{2}$ concentrations grow to their maximum a little more than a month later. An additional point is that although the pulsing behavior of $\mathrm{NH}_{3}$ appears to diminish in May and June, total $\mathrm{NH}_{3}$ emissions during those months are almost as elevated relative to the dry period as emissions during March and April (167 and $173 \mathrm{mg} \mathrm{N} \mathrm{m}^{-2}$ for each 61-day period, respectively; Fig. 6). Consequently, it could be argued that May and June remain important months for both $\mathrm{NO}_{2}$ and $\mathrm{NH}_{3}$ emissions. For a presentation of modeled emissions calculated based only on grid cells that have satellite observations for both gases, see Fig. S3. This additional screening reduces annual modeled $\mathrm{NH}_{3}$ emissions by roughly $5 \%$ and reduces modeled emissions during the pulses by roughly 2 $3 \%$ relative to modeled $\mathrm{NH}_{3}$ emissions that do not take the presence or absence of $\mathrm{NO}_{2}$ observations into account.

In addition, both $\mathrm{NH}_{3}$ volatilization and nitrification are dependent on $\mathrm{NH}_{4}^{+}$availability, and thus competition between these processes for $\mathrm{NH}_{4}^{+}$is likely to contribute to the observed temporal dynamics of atmospheric $\mathrm{NH}_{3}$ and $\mathrm{NO}_{2}$ concentrations. The increased competition for available $\mathrm{NH}_{4}^{+}$ from growing nitrifier populations could contribute to the observed decline in $\mathrm{NH}_{3}$ emissions between April and May. Earlier researchers have hypothesized that competition between $\mathrm{NH}_{3}$ volatilization and nitrification for $\mathrm{NH}_{4}^{+}$is so extreme that the two processes cannot occur at the same time (Praveen-Kumar and Aggarwal, 1998). However, soil emissions of $\mathrm{NO}$ and $\mathrm{NH}_{3}$ have been shown to be broadly coupled in the Sahel (Delon et al., 2018), and the few field and lab studies measuring soil emissions of both gases following wetting observe positive fluxes of each (McCalley and Sparks, 2008; Schlesinger and Peterjohn, 1991; Soper et al., 2016), with $\mathrm{NH}_{3}$ dominating emissions from desert soils (McCalley and Sparks, 2008; Schlesinger and Peterjohn, 1991) and NO dominating from grassland soils (Soper et al., 2016). Our findings contrast with those of Soper et al. (2016) as $\mathrm{NH}_{3}$ appears to be the dominant species emitted during pulse events in March and April from the Sahelian grassland soils (Fig. 6), though NO may dominate later in the season during the period focused on by Jaeglé et al. (2004). We expect that even if the two processes were mutually exclusive at the scale of a soil core or chamber, heterogeneity in soil properties at the grid cell or regional scale would explain our observations of coinciding peaks of $\mathrm{NO}_{2}$ and $\mathrm{NH}_{3}$.

\subsection{Magnitude and importance of soil $\mathrm{NH}_{3}$ emission pulses}

During the early growing season, atmospheric concentrations of $\mathrm{NH}_{3}$ are roughly an order of magnitude higher than $\mathrm{NO}_{2}$ (Fig. 2). It is important to note that $\mathrm{NH}_{3}$ retrievals generally have a higher error and that our screening process may introduce a potential bias in that we permit retrievals with higher uncertainty if they are low concentrations; we also retain observations of negative concentrations. In addition, as mentioned earlier, compared to FTIR observations the IASI total columns are biased low by $\sim 30 \%$, which varies per region depending on the local concentrations. From this perspective, our concentration and emission estimates can be considered conservative.

Because the magnitude of mean surface fluxes depends on the effective lifetime used in the simple box model, comparisons between the modeled fluxes of $\mathrm{NO}_{2}$ and $\mathrm{NH}_{3}$ are not straightforward. It is also important to note the simplifying assumption of a uniform atmospheric profile in the box model, which ignores any variation in vertical distribution. Still, we believe a uniform profile is a reasonable assumption, especially for soil fluxes. Each of these gases has relatively short lifetimes and, unlike fire plumes, are unlikely to be rapidly lofted to high altitudes following emission from soil. In addition, there is very little variation in $\mathrm{NH}_{3}$ distribution throughout the boundary layer in the assumed IASI profile. In general, our modeled emissions suggest that $\mathrm{NH}_{3}$ is probably emitted at substantially higher rates from soils than NO during pulse events (Fig. 6). This result is unex- 
(a)

TRMM precipitation ( $\mathrm{mm}$ )
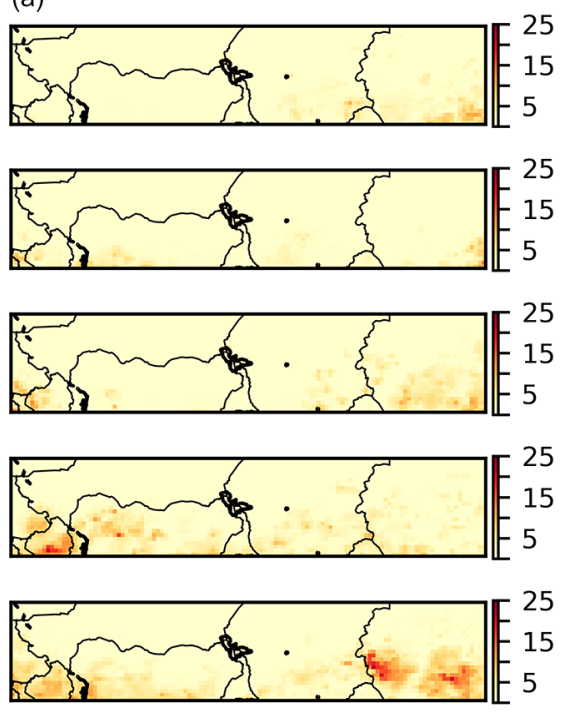

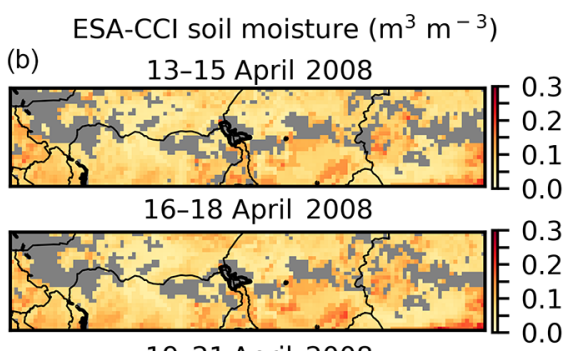

19-21 April 2008

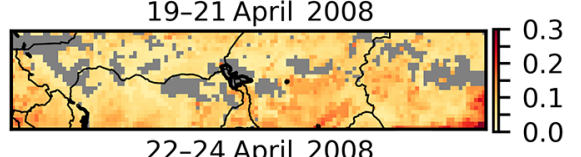

22-24 April 2008

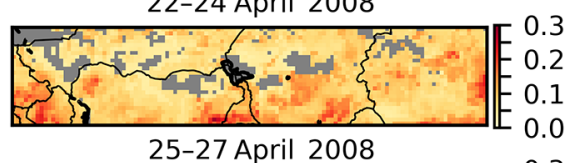

25-27 April 2008

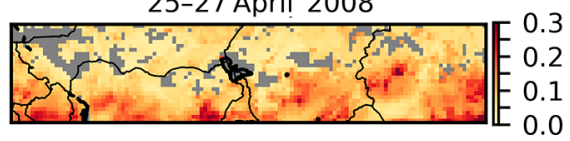

IASI $\mathrm{NH}_{3}\left(10^{16}\right.$ molecules $\left.\mathrm{cm}^{-2}\right)$

(c)
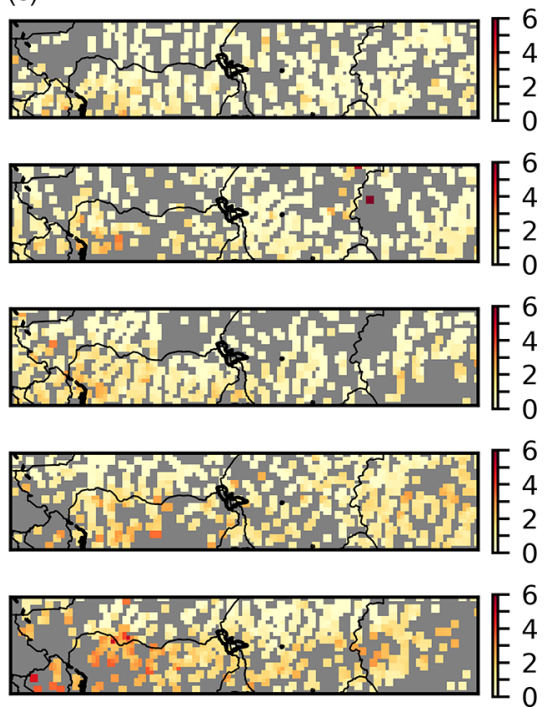

Figure 5. Maps of changing precipitation, soil moisture, and atmospheric $\mathrm{NH}_{3}$ concentrations for the focal region of the Sahel during the second half of April 2008. 3-day averages from 13 April through 27 April are presented for precipitation from TRMM (a), soil moisture from ESA-CCI (b), and atmospheric $\mathrm{NH}_{3}$ concentrations for acceptable retrievals from IASI (c).
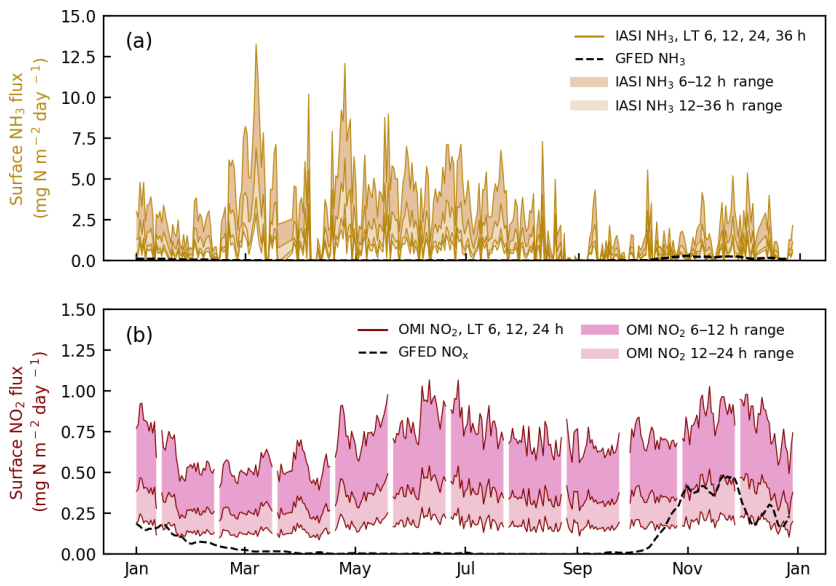

Figure 6. Comparison of daily total surface fluxes and biomass burning emissions of (a) $\mathrm{NH}_{3}-\mathrm{N}$ and (b) $\mathrm{NO}_{2}-\mathrm{N}$ for the focal study region in the Sahel during 2008. Total surface fluxes are estimated from IASI $\mathrm{NH}_{3}$ and $\mathrm{OMI} \mathrm{NO}_{2}$ observations using a simple box model and assuming effective lifetimes of $6,12,24$, or $36 \mathrm{~h}$ for $\mathrm{NH}_{3}$ and of 6,12 , or $24 \mathrm{~h}$ for $\mathrm{NO}_{2}$. Fire emissions are taken from the GFED4s database. Modeled $\mathrm{NO}_{2}$ emissions were calculated using values of $0.25^{\circ}$ grid cells within the study region for which $\mathrm{NH}_{3}$ observations were also present. GFED4s emission means were calculated using $0.25^{\circ}$ grid cells that matched those used in the modeled emissions for the respective gas. Note the difference in scales and that shorter effective lifetimes result in higher modeled emissions.

pected given earlier observations that $\mathrm{NH}_{3}$ tends to be the dominant source in highly alkaline desert soils ( $\mathrm{pH} 9-11$; McCalley and Sparks, 2008), whereas emissions from grass- land soils with a more neutral $\mathrm{pH}$, as might be expected in the Sahel, were dominated by NO by roughly a factor of $10: 1$ (Soper et al., 2016). This pulse produces $\mathrm{NH}_{3}$ concentrations comparable in magnitude to the peak concentrations over many of the Earth's major biomass burning regions (Whitburn et al., 2015). Indeed, $\mathrm{NH}_{3}$ emissions during the date range 29 February-16 March and 12 April-1 May, which cover the two emission peaks during that period, represented about one-fifth of annual $\mathrm{NH}_{3}$ emissions from our focal region in the Sahel (annual emissions of $\sim 0.4$ to $2 \mathrm{Tg} \mathrm{N}$ and total pulse emissions of $\sim 0.1$ to $0.5 \mathrm{Tg} \mathrm{N}$, depending on the effective lifetime assumed, but assuming that the mean effective lifetime during the pulses is equal to the mean effective lifetime throughout the year). It is important to note that in addition to uncertainty associated with the $\mathrm{NH}_{3}$ retrievals, additional sources of bias and uncertainty - such as the use of an effective lifetime rather than explicitly accounting for deposition fluxes and chemistry, uncertainty in the value and variability in that lifetime, and biases in both the IASI and OMI retrievals - limit our ability to quantitatively constrain the surface $\mathrm{NH}_{3}$ or $\mathrm{NO}_{2}$ fluxes or to make strict quantitative comparisons between them.

Within the Sahel, the March and April pulses are responsible for the highest concentrations of atmospheric $\mathrm{NH}_{3}$ during 2008. The magnitude of $\mathrm{NH}_{3}$ emissions during these pulses is of a similar magnitude as emissions from biomass burning in north equatorial Africa (Whitburn et al., 2015). This substantial pulse of $\mathrm{NH}_{3}$, and the co-occurrence of a pulse of $\mathrm{NO}_{x}$, could be an important source of $\mathrm{PM}_{2.5}$ in the region during the first half of the year. Secondary inorganic aerosols such as ammonium sulfate are formed in reactions involving 
$\mathrm{NH}_{3}$, and ammonium nitrate aerosol formation requires both gaseous $\mathrm{NH}_{3}$ and $\mathrm{NO}_{x}$. In the Sahel, combustion sources of $\mathrm{NO}_{2}$ are relatively small in March and April (Fig. 6), making soil NO emissions potentially more important in the formation of $\mathrm{PM}_{2.5}$.

\subsection{Comparison to surface observations}

The INDAAF network (International Network to Study Deposition and Atmospheric Chemistry in Africa; http://www. indaaf.obs-mip.fr, last access: December 2017) provides monthly surface $\mathrm{NH}_{3}$ deposition rates between 1998 and 2016 for seven sites in north equatorial Africa, both in and outside the Sahel. The work of Adon et al. (2010) presents an analysis of annual and seasonal variability of the concentrationsof surface gases, including $\mathrm{NO}_{2}$ and $\mathrm{NH}_{3}$ from the longterm monitoring INDAAF stations over the period 20002007. The sites in the Sahel (Agoufou, Mali, Banizoumbou, Niger, and Katibougou, Mali; Fig. 3b, c, f, respectively) exhibit broadly similar seasonal patterns, with $\mathrm{NH}_{3}$ concentration increases starting in April (or March in the 2008 case of Katibougou, Mali; Fig. 3f), but this seasonal pattern is generally absent in sites outside the Sahel (Fig. 3d, e, g, h). These seasonal patterns are broadly consistent with the pulsing dynamics observed by IASI in the Sahel and the absence of pulsing outside the Sahel (Fig. 3), though the peak concentrations observed at the surface tend to occur later than those observed by satellite in Banizoumbou and Katibougou.

Part of the difference in the timing of peak $\mathrm{NH}_{3}$ concentrations between the IASI observations and surface observations at Banizoumbou and Katibougou may be because of random variation and the effects of local influences, which are likely also responsible for variation among the three sites. Deterministic variation in $\mathrm{NH}_{3}$ emissions in the Sahel is likely also important. These sites are located at latitudes near the northern boundary of our focal area and could be influenced by emissions from the north. In addition, we observe a northsouth gradient in soil moisture, precipitation, and $\mathrm{NH}_{3}$ concentrations during the pulse event in April (Fig. 4), suggesting that pulsing is larger in the southern part of our focal area during this period. The onset of the rainy season tends to occur later in more northern latitudes, which would be consistent with higher $\mathrm{NH}_{3}$ concentrations observed later in the year in Banizoumbou and Katibougou. Indeed, IASI observations of $1^{\circ}$ grid cells over each of the three INDAAF sites show better agreement with the surface observations, with peak NH3 concentrations occurring in May for all sites during 2008 (Fig. S4).

Other factors may contribute to variation in $\mathrm{NH}_{3}$ concentrations observed across all the INDAAF sites. An earlier evaluation of seasonal patterns in the surface observation network found that emission patterns differ between wet savanna and dry savanna: dry season emissions tend to be higher in wet savanna where biomass burning dominates annual emissions (Adon et al., 2010). In dry savanna ecosys- tems, emissions are higher during the wet season and are likely enhanced by the volatilization of $\mathrm{N}$ inputs from agropastoralism in the region, leading to high total $\mathrm{N}$ deposition fluxes (Adon et al., 2010). It is conceivable that regional differences in soil pH (Vågen et al., 2016) could also result in different rates of soil $\mathrm{NH}_{3}$ emissions. In addition, higher leaf area index in wet savannas and forest could result in more interception of $\mathrm{NH}_{3}$, reducing soil contributions to atmospheric concentrations during the wet season.

\subsection{Later growing season $\mathrm{NH}_{3}$ emissions}

After the early season pulses, $\mathrm{NH}_{3}$ concentrations and fluxes remain fairly elevated (Figs. 2, 6); during this period of May through July, $\mathrm{NO}_{2}$ concentrations and fluxes increase, becoming closer in magnitude to $\mathrm{NH}_{3}$ (Figs. 2, 6). This pattern is consistent with earlier studies describing elevated concentrations of these gases in or near our focal study region for several months following the end of the biomass burning season (Jaeglé et al., 2004; Whitburn et al., 2015). Jaeglé et al. (2004) attribute these elevated $\mathrm{NO}_{2}$ concentrations to the wetting of dry soils, and Whitburn et al. (2015) attribute elevated $\mathrm{NH}_{3}$ concentrations to increasing surface temperatures and the possible acidification of soils. The mean start of the cropping season ranges from May to August in the focal region based on NDVI-based observations of plant phenology (Vrieling et al., 2011), suggesting that the bulk of elevated $\mathrm{NO}_{2}$ and $\mathrm{NH}_{3}$ in our modeled emissions occurs after planting and well into the rainy season. Elevated emissions could be associated with soil disturbance from tillage (e.g., Yang et al., 2015) or from the use of fertilizer inputs, which have been argued to be higher than generally acknowledged in the scientific and development literature (Cobo et al., 2010; Sheahan and Barrett, 2017). However, $\mathrm{N}$ additions in Sahelian countries such as Niger tend to be very low, even for farmers who use fertilizer (Masso et al., 2017; Sheahan and Barrett, 2017).

\subsection{Possible sources of error and bias}

It is worth noting that the morning overpass time used in this analysis is likely to cause a further underestimation of daily $\mathrm{NH}_{3}$ concentrations, as emissions would be expected to follow diurnal temperature variation and be higher in the afternoon (Van Damme et al., 2015). A more sophisticated inverse modeling approach (e.g., using a Bayesian approach in combination with an atmospheric chemical transport model) could provide firmer insight into the magnitude of emissions, as well as provide some insight into the magnitude of specific $\mathrm{NH}_{3}$ sources. Our analysis is subject to several additional sources of uncertainty: increased cloud cover during the rainy season tends to result in fewer observations than during the dry season, so our regional means are based on different numbers of observations at different times of year. 


\section{Conclusions}

Satellite measurements of trace gases - although not without their limitations - provide a powerful tool for understanding global and regional atmospheric composition and for gaining insights into the controls over nitrogen cycling and trace gas emissions, particularly for regions where other types of measurements are scarce. With daily and global coverage and additional satellite-observed variables such as precipitation, soil moisture, biomass burning emissions, and tropospheric $\mathrm{NO}_{2}$ concentrations, it is possible to evaluate specific mechanisms behind the seasonality of trace gas emissions. In an evaluation of the Sahel during 2008, we find that $\mathrm{NH}_{3}$ concentrations are elevated during March and April, a period when biomass burning emissions are absent, but when tropospheric $\mathrm{NO}_{2}$ concentrations exhibit similar temporal dynamics. We further find that the increase in $\mathrm{NH}_{3}$ concentrations is positively correlated with changes in soil moisture at the start of the rainy season. Using a simple box model, we estimate that average emissions for the entire Sahel are between 2 and $6 \mathrm{mg} \mathrm{NH}_{3}-\mathrm{N} \mathrm{m}^{-2} \mathrm{~d}^{-1}$ during peaks of the observed pulses, though we note that these estimates are subject to substantial bias and uncertainty. We conclude that the Birch effect is an important and geographically broad driver of $\mathrm{NH}_{3}$ emissions and an important component of the N cycle in the Sahel.

Data availability. This study relies entirely on publicly available data. IASI $\mathrm{NH}_{3}$ data are available at http://espri.aeris-data. fr/etherTypo/index.php?id=1727\&L=1. OMI NO 2 level-3 data are available at https://disc.gsfc.nasa.gov/datasets/OMNO2d_V003/ summary. The TRMM daily precipitation product $3 \mathrm{~B} 42$ is available at https://pmm.nasa.gov/data-access/downloads/trmm. ESA-CCI soil moisture data are available at https://www.esa-soilmoisture-cci. org/node/145. GFED4s $\mathrm{NO}_{2}$ and $\mathrm{NH}_{3}$ fire emissions data are available at https://www.globalfiredata.org/data.html. INDAAF surface observations of $\mathrm{NO}_{2}$ and $\mathrm{NH}_{3}$ are available at http://www.indaaf. obs-mip.fr (INDAAF, 2017).

Supplement. The supplement related to this article is available online at: https://doi.org/10.5194/acp-18-16713-2018-supplement.

Author contributions. JEH conceived of the study and conducted the analyses with contributions from GRW, ED, and CG-L. All authors wrote the paper.

Competing interests. The authors declare that they have no conflict of interest.

Acknowledgements. The IASI-NN observations were created by the atmospheric spectroscopy group at ULB (Spectroscopie de 645 l'Atmosphère, Service de Chimie Quantique et Photo-physique, Université Libre de Brux- elles, Brussels, Belgium) and were obtained from http://espri.aeris-data.fr/etherTypo/index.php?id=1727\&L=1 (last access: November 2017). We would like to thank Simon Whitburn, Martin Van Damme, Lieven Clarisse, and Pierre Francois Coheur for the retrieval product. Jonathan E. Hickman would also like to thank Shelly van der Graaf for her assistance in interpreting the IASI data.

Edited by: Michel Van Roozendael

Reviewed by: three anonymous referees

\section{References}

Adon, M., Galy-Lacaux, C., Yoboué, V., Delon, C., Lacaux, J. P., Castera, P., Gardrat, E., Pienaar, J., Al Ourabi, H., Laouali, D., Diop, B., Sigha-Nkamdjou, L., Akpo, A., Tathy, J. P., Lavenu, F., and Mougin, E.: Long term measurements of sulfur dioxide, nitrogen dioxide, ammonia, nitric acid and ozone in Africa using passive samplers, Atmos. Chem. Phys., 10, 7467-7487, https://doi.org/10.5194/acp-10-7467-2010, 2010.

Andela, N., Morton, D. C., Giglio, L., Chen, Y., van der Werf, G. R., Kasibhatla, P. S., DeFries, R. S., Collatz, G. J., Hantson, S., Kloster, S., Bachelet, D., Forrest, M., Lasslop, G., Li, F., Mangeon, S., Melton, J. R., Yue, C., and Randerson, J. T.: A humandriven decline in global burned area, Science, 356, 1356-1362, https://doi.org/10.1126/science.aal4108, 2017.

Anderson, I. C. and Levine, J. S.: Relative rates of nitric oxide and nitrous oxide production by nitrifiers, denitrifiers, and nitrate respirers, Appl. Environ. Microbiol., 51, 938-945, 1986.

Austin, A. T., Yahdjian, L., Stark, J. M., Belnap, J., Porporato, A., Norton, U., Ravetta, D. A., and Schaeffer, S. M.: Water pulses and biogeochemical cycles in arid and semiarid ecosystems, Oecologia, 141, 221-235, https://doi.org/10.1007/BF00335913, 2004.

Beirle, S., Boersma, K. F., Platt, U., Lawrence, M. G., and Wagner, T.: Megacity emissions and lifetimes of nitrogen oxides probed from space, Science, 333, 1737-1739, https://doi.org/10.1126/science.1207824, 2011.

Bergstrom, A.-K. and Jannson, M.: Atmospheric nitrogen deposition has caused nitrogen enrichment and eutrophication of lakes in the northern hemisphere, Glob. Change Biol., 12, 635-643, https://doi.org/10.1111/j.1365-2486.2006.01129.x, 2006.

Birch, H. F.: The effect of soil drying on humus decomposition and nitrogen availability, Plant Soil, 10, 9-31, 1958.

Birch, H. F.: Nitrification in soils after different periods of dryness, Plant Soil, 12, 81-96, 1960.

Birch, H. F. and Friend, M. T.: Humus decomposition in East African soils, Nature, 178, 500-501, 1956.

Bobbink, R., Hicks, K., Galloway, J., Spranger, T., Alkemade, R., Ashmore, M., Bustamante, M., Cinderby, S., Davidson, E., and Dentener, F.: Global assessment of nitrogen deposition effects on terrestrial plant diversity: a synthesis, Ecol. Appl., 20, 30-59, 2010.

Borken, W., and Matzner, E.: Reappraisal of drying and wetting effects on $\mathrm{C}$ and $\mathrm{N}$ mineralization and fluxes in soils, Glob. Change Biol., 15, 808-824, https://doi.org/10.1111/j.13652486.2008.01681.x, 2009. 
Bouwman, A. F., Lee, D. S., and Asman, W.: A global highresolution emission inventory for ammonia, Global Biogeochem. Cy., 11, 561-587, 1997.

Clarisse, L., Clerbaux, C., Dentener, F., Hurtmans, D., and Coheur, P.-F.: Global ammonia distribution derived from infrared satellite observations, Nat. Geosci., 2, 479-483, https://doi.org/10.1038/ngeo551, 2009.

Cobo, J. G., Dercon, G., and Cadisch, G.: Nutrient balances in African land use systems across different spatial scales: A review of approaches, challenges and progress, Agric. Ecosys. Environ., 136, 1-15, https://doi.org/10.1016/j.agee.2009.11.006, 2010.

Collins, S. L., Sinsabaugh, R. L., Crenshaw, C., Green, L., PorrasAlfaro, A., Stursova, M., and Zeglin, L. H.: Pulse dynamics and microbial processes in aridland ecosystems, J. Ecol., 96, 413420, https://doi.org/10.1111/j.1365-2745.2008.01362.x, 2008.

Dammers, E., Shephard, M. W., Palm, M., Cady-Pereira, K., Capps, S., Lutsch, E., Strong, K., Hannigan, J. W., Ortega, I., Toon, G. C., Stremme, W., Grutter, M., Jones, N., Smale, D., Siemons, J., Hrpcek, K., Tremblay, D., Schaap, M., Notholt, J., and Erisman, J. W.: Validation of the CrIS fast physical $\mathrm{NH}_{3}$ retrieval with ground-based FTIR, Atmos. Meas. Tech., 10, 2645-2667, https://doi.org/10.5194/amt-10-2645-2017, 2017.

Davidson, E. A.: Pulses of nitric oxide and nitrous oxide flux following wetting of dry soil: An assessment of probable sources and importance relative to annual fluxes, Ecol. Bull., 42, 149$155,1992$.

Davidson, E. A., Vitousek, P. M., Matson, P. A., Riley, R., GarcíaMéndez, G., and Maass, J. M.: Soil emissions of nitric oxide in a seasonally dry tropical forest of México, J. Geophys. Res.Biogeo., 96, 15439-15445, https://doi.org/10.1029/91JD01476, 1991.

Dawson, G. A.: Atmospheric ammonia from undisturbed land, J. Geophys. Res.-Biogeo., 82, 3125-3133, 1977.

de Foy, B., Lu, Z., Streets, D. G., Lamsal, L. N., and Duncan, B. N.: Estimates of power plant $\mathrm{NO}_{x}$ emissions and lifetimes from $\mathrm{OMI} \mathrm{NO}_{2}$ satellite retrievals, Atmos. Environ., 116, 1-11, https://doi.org/10.1016/j.atmosenv.2015.05.056, 2015.

Delon, C., Galy-Lacaux, C., Serca, D., Loubet, B., Camara, N., Gardrat, E., Saneh, I., Fensholt, R., Tagesson, T., Le Dantec, V., Sambou, B., Diop, C., and Mougin, E.: Soil and vegetation-atmosphere exchange of NO, $\mathrm{NH}_{3}$, and $\mathrm{N}_{2} \mathrm{O}$ from field measurements in a semi arid grazed ecosystem in Senegal, Atmos. Environ., 156, 36-51, https://doi.org/10.1016/j.atmosenv.2017.02.024, 2017.

Delon, C., Galy-Lacaux, C., Serça, D., Personne, E., Mougin, E., Adon, M., Le Dantec, V., Loubet, B., Fensholt, R., and Tagesson, T.: Modelling land atmosphere daily exchanges of $\mathrm{NO}, \mathrm{NH}_{3}$, and $\mathrm{CO}_{2}$ in a semi-arid grazed ecosystem in Senegal, Biogeosciences Discuss., https://doi.org/10.5194/bg-2018-366, in review, 2018.

Dentener, F. J. and Crutzen, P. J.: A three-dimensional model of the global ammonia cycle, J. Atmos. Chem., 19, 331-369, https://doi.org/10.1007/BF00694492, 1994.

Dentener, F., Drevet, J., Lamarque, J. F., Bey, I., Eickhout, B., Fiore, A. M., Hauglustaine, D., Horowitz, L. W., Krol, M., Kulshrestha, U. C., Lawrence, M., Galy-Lacaux, C., Rast, S., Shindell, D., Stevenson, D., Van Noije, T., Atherton, C., Bell, N., Bergman, D., Butler, T., Cofala, J., Collins, B., Doherty, R., Ellingsen, K., Galloway, J., Gauss, M., Montanaro, V., Müller, J. F., Pitari, G., Rodriguez, J., Sanderson, M., Solmon, F., Stra- han, S., Schultz, M., Sudo, K., Szopa, S., and Wild, O.: Nitrogen and sulfur deposition on regional and global scales: A multimodel evaluation, Glob. Biogeochem. Cy., 20, GB4003, https://doi.org/10.1029/2005GB002672, 2006.

Dick, J., Skiba, U., and Wilson, J.: The Effect of Rainfall on NO and $\mathrm{N}_{2} \mathrm{O}$ Emissions from Ugandan Agroforest Soils, Phyton, 41, 73-80, 2001.

Dijkstra, F. A., Augustine, D. J., Brewer, P., and Fischer, von, J. C.: Nitrogen cycling and water pulses in semiarid grasslands: are microbial and plant processes temporally asynchronous? Oecoliga, 170, 799-808, https://doi.org/10.1007/s10021-010-9341-6, 2012.

Dorigo, W. A., Gruber, A., De Jeu, R. A. M., Wagner, W., Stacke, T., Loew, A., Albergel, C., Brocca, L., Chung, D., Parinussa, R. M., and Kidd, R.: Evaluation of the ESA CCI soil moisture product using ground-based observations, Remote Sens. Environ., 162, 380-395, https://doi.org/10.1016/j.rse.2014.07.023, 2014.

Dorigo, W., Wagner, W., Albergel, C., Albrecht, F., Balsamo, G., Brocca, L., Chung, D., Ertl, M., Forkel, M., Gruber, A., Haas, E., Hamer, P. D., Hirschi, M., Ikonen, J., de Jeu, R., Kidd, R., Lahoz, W., Liu, Y. Y., Miralles, D., Mistelbauer, T., Nicolai-Shaw, N., Parinussa, R., Pratola, C., Reimer, C., van der Schalie, R., Seneviratne, S. I., Smolander, T., and Lecomte, P.: ESA CCI Soil Moisture for improved Earth system understanding: State-of-the art and future directions, Remote Sens. Environ., 203, 185-215, https://doi.org/10.1016/j.rse.2017.07.001, 2017.

Duncan, B. N.: Interannual and seasonal variability of biomass burning emissions constrained by satellite observations, J. Geophys. Res.-Biol., 108, 73-28, https://doi.org/10.1029/2002JD002378, 2003.

Eickenscheidt, N., Brumme, R., and Veldkamp, E.: Direct contribution of nitrogen deposition to nitrous oxide emissions in a temperate beech and spruce forest - a ${ }^{15} \mathrm{~N}$ tracer study, Biogeosciences, 8, 621-635, https://doi.org/10.5194/bg-8-6212011, 2011.

Emmerich, W. E.: Carbon dioxide fluxes in a semiarid environment with high carbonate soils, Agr. Forest Meteorol., 116, 91-102, https://doi.org/10.1016/S0168-1923(02)00231-9, 2003.

European Commission, Joint Research Center (JRC)/Netherlands Environmental Agency (PBL): Emission Database for Global Atmospheric Research (EDGAR), release version 4.2, available at: http://edgar.jrc.ed.europa.eu, last access: January 2014.

FAO: FAOSTAT database collections, available at: http://faostat.fao. org, last access: January 2018.

Galy-Lacaux, C. and Delon, C.: Nitrogen emission and deposition budget in West and Central Africa, Environ. Res. Lett., 9, 125002-125014, https://doi.org/10.1088/17489326/9/12/125002, 2014

Giglio, L., Randerson, J. T., and van der Werf, G. R.: Analysis of daily, monthly, and annual burned area using the fourthgeneration global fire emissions database (GFED4), J. Geophys. Res.-Biogeo., 118, 317-328, https://doi.org/10.1002/jgrg.20042, 2013.

Giglio, L., van der Werf, G. R., Randerson, J. T., Collatz, G. J., and Kasibhatla, P.: Global estimation of burned area using MODIS active fire observations, Atmos. Chem. Phys., 6, 957974, https://doi.org/10.5194/acp-6-957-2006, 2006.

Gruber, A., Dorigo, W. A., Crow, W., and Wagner, W.: Triple Collocation-Based Merging of Satellite Soil Moisture Re- 
trievals, IEEE T. Geosci. Remote Sens., 55, 6780-6792, https://doi.org/10.1109/TGRS.2017.2734070, 2017.

Hickman, J. E., Huang, Y., Wu, S., Diru, W., Groffman, P. M., Tully, K. L., and Palm, C. A.: Nonlinear response of nitric oxide fluxes to fertilizer inputs and the impacts of agricultural intensification on tropospheric ozone pollution in Kenya, Glob. Change Biol., 23, 3193-3204, https://doi.org/10.1029/95JD00370, 2017.

Holland, E., Braswell, B., Sulzman, J., and Lamarque, J.: Nitrogen deposition onto the United States and western Europe: Synthesis of observations and models, Ecol. Appl., 15, 38-57, 2005.

Huffman, G. J., Bolvin, D. T., Nelkin, E. J., Wolff, D. B., Adler, R. F., Gu, G., Hong, Y., Bowman, K. P., and Stocker, E. F.: The TRMM Multi-satellite Precipitation Analysis: Quasi-Global, Multi-Year, Combined-Sensor Precipitation Estimates at Fine Scale, J. Hydrometeorol., 8, 38-55, https://doi.org/10.1175/jhm560.1, 2007.

Huxman, T. E., Snyder, K. A., Tissue, D., Leffler, A. J., Ogle, K., Pockman, W. T., Sandquist, D. R., Potts, D. L., and Schwinning, S.: Precipitation pulses and carbon fluxes in semiarid and arid ecosystems, Oecoliga, 141, 254-268, https://doi.org/10.1007/s00442-004-1682-4, 2004.

INDAAF: International Network to study Deposition and Atmospheric chemistry in Africa, https://indaaf.obs-mip.fr/, last access: December 2017.

Jacob, D. J.: Introduction to Atmospheric Chemistry, Princeton University Press, Princeton, United States, 1999.

Jaeglé, L., Martin, R. V., Chance, K., Steinberger, L., Kurosu, T. P., Jacob, D. J., Modi, A. I., Yoboue, V., Sigha-Nkamdjou, L., and Galy-Lacaux, C.: Satellite mapping of rain-induced nitric oxide emissions from soils, J. Geophys. Res.-Biogeo., 109, D21310, 2004.

Jena, C., Ghude, S. D., Blond, N., Beig, G., Chate, D. M., Fadnavis, S., and Van der A, R. J.: Estimation of the lifetime of nitrogen oxides over India using SCIAMACHY observations, Intl. J. Remote Sens., 35, 1244-1252, https://doi.org/10.1080/01431161.2013.873146, 2014.

Kieft, T., Soroker, E., and Firestone, M. K.: Microbial biomass response to a rapid increase in water potential when dry soil is wetted, Soil Biol. Biochem., 2, 119-126, 1987.

Kim, D.-G., Vargas, R., Bond-Lamberty, B., and Turetsky, M. R.: Effects of soil rewetting and thawing on soil gas fluxes: a review of current literature and suggestions for future research, Biogeosciences, 9, 2459-2483, https://doi.org/10.5194/bg-9-24592012, 2012.

Krotkov, N. A.: OMI/Aura $\mathrm{NO}_{2}$ Cloud-Screened Total and Tropospheric Column L3 Global Gridded $0.25^{\circ} \times 0.25^{\circ}$ V3, https://doi.org/10.5067/Aura/OMI/DATA3007, last access: January 2018.

Krotkov, N. A., Lamsal, L. N., Celarier, E. A., Swartz, W. H., Marchenko, S. V., Bucsela, E. J., Chan, K. L., Wenig, M., and Zara, M.: The version $3 \mathrm{OMI} \mathrm{NO}_{2}$ standard product, Atmos. Meas. Tech., 10, 3133-3149, https://doi.org/10.5194/amt10-3133-2017, 2017.

Lamarque, J.-F., Bond, T. C., Eyring, V., Granier, C., Heil, A., Klimont, Z., Lee, D., Liousse, C., Mieville, A., Owen, B., Schultz, M. G., Shindell, D., Smith, S. J., Stehfest, E., Van Aardenne, J., Cooper, O. R., Kainuma, M., Mahowald, N., McConnell, J. R., Naik, V., Riahi, K., and van Vuuren, D. P.: Historical (1850-2000) gridded anthropogenic and biomass burning emissions of reactive gases and aerosols: methodology and application, Atmos. Chem. Phys., 10, 7017-7039, https://doi.org/10.5194/acp-10-7017-2010, 2010.

Lamsal, L. N., Krotkov, N. A., Celarier, E. A., Swartz, W. H., Pickering, K. E., Bucsela, E. J., Gleason, J. F., Martin, R. V., Philip, S., Irie, H., Cede, A., Herman, J., Weinheimer, A., Szykman, J. J., and Knepp, T. N.: Evaluation of OMI operational standard $\mathrm{NO}_{2}$ column retrievals using in situ and surface-based $\mathrm{NO}_{2}$ observations, Atmos. Chem. Phys., 14, 11587-11609, https://doi.org/10.5194/acp-14-11587-2014, 2014.

Laouali, D., Galy-Lacaux, C., Diop, B., Delon, C., Orange, D., Lacaux, J. P., Akpo, A., Lavenu, F., Gardrat, E., and Castera, P.: Long term monitoring of the chemical composition of precipitation and wet deposition fluxes over three Sahelian savannas, Atmos. Environ., 50, 314-327, https://doi.org/10.1016/j.atmosenv.2011.12.004, 2012.

Lelieveld, J., Evans, J. S., Fnais, M., Giannadaki, D., and Pozzer, A.: The contribution of outdoor air pollution sources to premature mortality on a global scale, Nature, 525, 367-371, https://doi.org/10.1038/nature15371, 2015.

Liu, Y. Y., Dorigo, W. A., Parinussa, R. M., de Jeu, R. A. M., Wagner, W., McCabe, M. F., Evans, J. P., and van Dijk, A. I. J. M.: Trend-preserving blending of passive and active microwave soil moisture retrievals, Remote Sens. Environ., 123, 280-297, https://doi.org/10.1016/j.rse.2012.03.014, 2012.

Masso, C., Nziguheba, G., Mutegi, J., Galy-Lacaux, C., Wendt, J., Butterbach-Bahl, K., Wairegi, L., and Datta, A.: Soil fertility management in sub-Saharan Africa, in Sustainable Agriculture Reviews, edited by: E. Lichtfouse, Springer International Publishing, Cham. 2017.

McCalley, C. K. and Sparks, J. P.: Controls over nitric oxide and ammonia emissions from Mojave Desert soils, Oecoliga, 156, 871-881, https://doi.org/10.1007/s00442-008-1031-0, 2008.

McLinden, C. A., Fioletov, V., Boersma, K. F., Kharol, S. K., Krotkov, N., Lamsal, L., Makar, P. A., Martin, R. V., Veefkind, J. P., and Yang, K.: Improved satellite retrievals of $\mathrm{NO}_{2}$ and $\mathrm{SO}_{2}$ over the Canadian oil sands and comparisons with surface measurements, Atmos. Chem. Phys., 14, 3637-3656, https://doi.org/10.5194/acp-14-3637-2014, 2014.

McNally, A., Shukla, S., Arsenault, K. R., Wang, S., Peters-Lidard, C. D., and Verdin, J. P.: Int. J. Appl. Earth Obs., 48, 96-109, https://doi.org/10.1016/j.jag.2016.01.001, 2016.

Meixner, F. X., Fickinger, T., Marufu, L., Serca, D., Nathaus, F. J., Makina, E., Mukurumbira, L., and Andreae, M. O.: Preliminary results on nitric oxide emission from a southern African savanna ecosystem, Nutr. Cy. Agroecosys., 48, 123-138, 1997.

Nelson, D. W.: Gaseous Losses of Nitrogen Other Than Through Denitrification, in Nitrogen, in: Nitrogen in Agricultural Soils, edited by: Stevenson, F. J., ASA-CSSA-SSSA, Madison, United States, 327-363, 1982.

Nicholson, S. E., Some, B., McCollum, J., Nelkin, E., Klotter, D., Berte, Y., Diallo, B. M., Gaye, I., Kpabeba, G., Ndiaye, O., Noukpozounkou, J. N., Tanu, M. M., Thiam, A., Toure, A. A., and Traore, A. K.: Validation of TRMM and Other Rainfall Estimates with a High-Density Gauge Dataset for West Africa. Part I: Validation of GPCC Rainfall Product and Pre-TRMM Satellite and Blended Products, J. Appl. Meteorol., 42, 1337-1354, https://doi.org/10.1175/15200450(2003)042<1337:votaor>2.0.co;2, 2003. 
Paulot, F. and Jacob, D. J.: Hidden Cost of U.S. Agricultural Exports: Particulate Matter from Ammonia Emissions, Environ. Sci. Technol., 48, 903-908, https://doi.org/10.1021/es4034793, 2014.

Pilegaard, K., Skiba, U., Ambus, P., Beier, C., Brüggemann, N., Butterbach-Bahl, K., Dick, J., Dorsey, J., Duyzer, J., Gallagher, M., Gasche, R., Horvath, L., Kitzler, B., Leip, A., Pihlatie, M. K., Rosenkranz, P., Seufert, G., Vesala, T., Westrate, H., and Zechmeister-Boltenstern, S.: Factors controlling regional differences in forest soil emission of nitrogen oxides ( $\mathrm{NO}$ and $\mathrm{N}_{2} \mathrm{O}$ ), Biogeosciences, 3, 651-661, https://doi.org/10.5194/bg-3-6512006, 2006.

Placella, S. A. and Firestone, M. K.: Transcriptional Response of Nitrifying Communities to Wetting of Dry Soil, Appl. Environ. Microbiol., 79, 3294-3302, https://doi.org/10.1128/AEM.00404-13, 2013.

Placella, S. A., Brodie, E. L., and Firestone, M. K.: Rainfall-induced carbon dioxide pulses result from sequential resuscitation of phylogenetically clustered microbial groups, P. Natl. Acad. Sci. USA, 109, 10931-10936, 2012.

Potter, C. S., Randerson, J. T., Field, C. B., Matson, P. A., Vitousek, P. M., Mooney, H. A., and Klooster, S. A.: Terrestrial ecosystem production: A process model based on global satellite and surface data, Glob. Biogeochem. Cy., 7, 811-841, https://doi.org/10.1029/93GB02725, 1993.

Praveen-Kumar and Aggarwal, R. K.: Interdependence of ammonia volatilization and nitrification in arid soils, Nutr. Cy. Agroecosys., 51, 201-207, https://doi.org/10.1023/A:1009720003490, 1998.

Randerson, J. T., Chen, Y., van der Werf, G. R., Rogers, B. M., and Morton, D. C.: Global burned area and biomass burning emissions from small fires, J. Geophys. Res.-Biogeo., 117, G04012, https://doi.org/10.1029/2012JG002128, 2012.

Robertson, G. P. and Groffman, P. M.: Nitrogen transformations, edited by: E. A. Paul, 341-364, Soil microbiology, Ecology, and Biochemistry, 3 Edn. Academic/Elsevier, New York, 2007.

Robinson, T. P., Wint, G. R. W., Conchedda, G., Van Boeckel, T. P., Ercoli, V., Palamara, E., Cinardi, G., D’Aietti, L., Hay, S. I., and Gilbert, M.: Mapping the Global Distribution of Livestock, PLoS ONE, 9, e96084, https://doi.org/10.1371/journal.pone.0096084, 2014.

Saetre, P. and Stark, J. M.: Microbial dynamics and carbon and nitrogen cycling following re-wetting of soils beneath two semi-arid plant species, Oecoliga, 142, 247-260, https://doi.org/10.1007/s00442-004-1718-9, 2004.

Schlesinger, W. H. and Peterjohn, W. T.: Processes controlling ammonia volatilization from Chihuahuan desert soils, Soil Biol. Biochem., 23, 637-642, 1991.

Semb, G. and Robinson, J. B. D.: The natural nitrogen flush in different arable soils and climates in East Africa, E. Afr. Agric. Forestry J., 34, 350-370, 1969.

Sheahan, M. and Barrett, C. B.: Ten striking facts about agricultural input use in Sub-Saharan Africa, Food Policy, 67, 12-25, https://doi.org/10.1016/j.foodpol.2016.09.010, 2017.

Slessarev, E. W., Lin, Y., Bingham, N. L., Johnson, J. E., Dai, Y., Schimel, J. P., and Chadwick, O. A.: Water balance creates a threshold in soil $\mathrm{pH}$ at the global scale, Nature, 540, 567-569, https://doi.org/10.1038/nature20139, 2016.
Soper, F. M., Boutton, T. W., Groffman, P. M., and Sparks, J. P.: Nitrogen trace gas fluxes from a semiarid subtropical savanna under woody legume encroachment, Glob. Biogeochem. Cy., 30, 614-628, https://doi.org/10.1002/2015gb005298, 2016.

Thomas, R. Q., Canham, C. D., Weathers, K. C., and Goodale, C. L.: Increased tree carbon storage in response to nitrogen deposition in the US, Nat. Geosci., 3, 13-17, https://doi.org/10.1038/ngeo721, 2009.

Tian, D. and Niu, S.: A global analysis of soil acidification caused by nitrogen addition, Environ. Res. Lett., 10, 024019, https://doi.org/10.1088/1748-9326/10/2/024019, 2015.

Van Damme, M., Clarisse, L., Heald, C. L., Hurtmans, D., Ngadi, Y., Clerbaux, C., Dolman, A. J., Erisman, J. W., and Coheur, P. F.: Global distributions, time series and error characterization of atmospheric ammonia (NH3) from IASI satellite observations, Atmos. Chem. Phys., 14, 2905-2922, https://doi.org/10.5194/acp14-2905-2014, 2014.

Van Damme, M., Erisman, J. W., and Clarisse, L.: Worldwide spatiotemporal atmospheric ammonia $\left(\mathrm{NH}_{3}\right)$ columns variability revealed by satellite, Geophys. Res. Lett., 42, 8660-8668, https://doi.org/10.1002/(ISSN)1944-8007, 2015.

van der Werf, G. R., Randerson, J. T., Giglio, L., van Leeuwen, T. T., Chen, Y., Rogers, B. M., Mu, M., van Marle, M. J. E., Morton, D. C., Collatz, G. J., Yokelson, R. J., and Kasibhatla, P. S.: Global fire emissions estimates during 1997-2016, Earth Syst. Sci. Data, 9, 697-720, https://doi.org/10.5194/essd-9-697-2017, 2017.

Vågen, T.-G., Winowiecki, L. A., Tondoh, J. E., Desta, L. T., and Gumbricht, T.: Mapping of soil properties and land degradation risk in Africa using MODIS reflectance, Geoderma, 263, 216225, https://doi.org/10.1016/j.geoderma.2015.06.023, 2016.

Vrieling, A., de Beurs, K. M., and Brown, M. E.: Variability of African farming systems from phenological analysis of NDVI time series, Clim. Change, 109, 455-477, https://doi.org/10.1029/2004JD005263, 2011.

Whitburn, S., Van Damme, M., and Clarisse, L.: A flexible and robust neural network IASI-NH3 retrieval algorithm, J. Geophys. Res.-Atmos., 121, 6581-6599, https://doi.org/10.1002/(ISSN)2169-8996, 2016.

Whitburn, S., Van Damme, M., Kaiser, J. W., van der Werf, G. R., Turquety, S., Hurtmans, D., Clarisse, L., Clerbaux, C., and Coheur, P. F.: Ammonia emissions in tropical biomass burning regions: Comparison between satellite-derived emissions and bottom-up fire inventories, Atmos. Environ., 121, 42-54, https://doi.org/10.1016/j.atmosenv.2015.03.015, 2015.

Yahdjian, L. and Sala, O. E.: Size of Precipitation Pulses Controls Nitrogen Transformation and Losses in an Arid Patagonian Ecosystem, Ecosystems, 13, 575-585, https://doi.org/10.1007/s10021-010-9341-6, 2010.

Yang, Y., Zhou, C., Li, N., Han, K., Meng, Y., Tian, X., and Wang, L.: Effects of conservation tillage practices on ammonia emissions from Loess Plateau rainfed winter wheat fields, Atmos. Environ., 104, 59-68, https://doi.org/10.1016/j.atmosenv.2015.01.007, 2015. 